ANUARIO DE ESTUDIOS MEDIEVALES 42/2, julio-diciembre de 2012, pp. 535-565

ISSN 0066-5061

doi:10.3989/aem.2012.42.2.02

\title{
APOSENTOS DE LA MEMORIA DINÁSTICA. MUDANZA Y ESTABILIDAD EN LOS PANTEONES REGIOS LEONESES (1157-1230)
}

\author{
DWELLINGS OF DYNASTIC MEMORY. \\ CHANGE AND STABILITY IN THE ROYAL PANTHEON IN LEON \\ (1157-1230)
}

\author{
GERARDO BOTO VARELA \\ Universitat de Girona
}

\begin{abstract}
Resumen: En la catedral de Santiago de Compostela culmina la historia de los panteones del reino de León. Es plausible considerar que antes de ocupar la capilla de Santa Catalina, las tumbas regias se reservaron en otro lugar, quizá alguno con vocación cementerial. La morfología de los panteones leoneses no fue homogénea a lo largo de tres siglos. Planteo si el conjunto de cementerios observó o no una continuidad o si esta idea responde a la visión de cronistas e historiadores.
\end{abstract}

Palabras clave: reino de León; cementerios regios; catedral de Santiago de Compostela; Fernando II; Alfonso IX.

\begin{abstract}
The history of the royal burial places of the Kingdom of León culminates in the Cathedral of Santiago de Compostela. It is possible to consider that in this cathedral, before occupying the chapel of Santa Catalina, the royal tombs had been kept elsewhere, perhaps in a place with specific burial purpose. The morphology of the burial places of the kings of León was not homogeneous throughout three centuries. My aim is to discuss whether or not the notion of continuity was observed in the royal cemeteries as a whole, or if this continuity is the result of the views of chroniclers and historians.
\end{abstract}

Keywords: kingdom of Leon; royal tombs; cathedral of Santiago de Compostela; Fernando II; Alfonso IX.

\section{SUMARIO}

1. Panteones e historia medieval hispana.- 2. Los primeros panteones leoneses: la capital regia y Sahagún.- 3. Un panteón bajo la Gloria. El proyecto compostelano de Fernando II y su metamorfosis.- 4. Tumbas inconclusas. La nueva corona y la discriminación de los pretéritos perfectos.- 5. Bibliografía citada.

1 Este trabajo parte de un seminario impartido en el "Groupe de Recherche en Histoire Médiévale" de l'Univesité Libre de Bruxelles (mayo de 2010) bajo la invitación de Jacqueline Leclecq-Marx, Jean-Marie Santerre y Alain Dierkens. Dejo constancia de mi agradecimiento a todos ellos. El artículo que aquí se presenta requiere de la lectura de G. Boto, Panteones regios leoneses (1020-1109) (en prensa) en el que evalúo las fórmulas topográficas, las implicaciones políticas y las coyunturas históricas de los tres primeros panteones del reino leonés, a los que en estas páginas sólo aludiré a vuelapluma. France.

Abreviaturas utilizadas: $\mathrm{AHN}=$ Archivo Histórico Nacional; $\mathrm{BnF}=$ Bibliothèque nationale de 


\section{PANTEONES E HISTORIA MEDIEVAL HISPANA}

Los sepulcros de los monarcas constituyen el depósito de sus huesos, pero también los receptáculos de la memoria de sus respectivos gobiernos. Cuando dos o más tumbas regias fueron alojadas en un mismo cementerio, independientemente de su morfología y ubicación, resultó ostensible la voluntad de denotar una ligazón entre los distintos soberanos y, por ahí, loar una prolongación del poder regio, más allá incluso de si sus protagonistas formaron parte de una misma dinastía. Navarro era Fernando I y toda la historiografía reconoce en su decisión de inhumarse en San Isidoro el propósito de enlazar con el linaje asturleonés de su esposa; la dinastía borgoñona multiplicó sus panteones, pero el de Toledo recobró vigor y vigencia de la mano de los Trastámara, acaso por el mismo afán de legitimación que ansiaba Fernando I. Los panteones regios no exhiben tanto la unidad familiar y consanguinidad cuanto una genealogía del poder y, con ello, el principio de sucesión -legítima o legitimada a la postre- que se sustancia en el reino heredado, entendiendo por reino tanto la capacidad de ejercer el poder como el territorio expansivo en el que aquel se despliega.

La abultada producción bibliográfica centrada en los cementerios regios ha prosperado en el examen de los acontecimientos y las circunstancias que concurrieron en el caso específico de cada rey. Desde hace décadas, los estudios pretenden esclarecer cuáles fueron las aspiraciones personales, pero también los fundamentos ideológicos que motivaron la monumentalización de las tumbas de los soberanos pasados. En otras palabras, se ha procurado verificar los criterios que determinaron que el sarcófago fuera preciado como monumentum de su vida y de sus obras ${ }^{2}$. En este sentido, ha resultado capital comprender en qué medida los panteones fueron interpretados como uno de los puntales sobre los que reposaba la justificación del rey del presente -cualquiera que fuese este-, de sus acciones tanto como de su posición en la historia. Las tumbas de los monarcas, como las crónicas, se labraron para servir de hitos memoriales y, así, conceder un proteico futuro al pasado.

La investigación histórica ha formulado distintas explicaciones respecto al bagaje memorial acarreado por las cuatro decenas de tumbas de reyes asturianos, leoneses, castellanos y castellano-leoneses (dejando al margen los interesantísimos y múltiples monarcas navarros, aragoneses y portugueses). Se ha intentado dilucidar, más específicamente, qué motivó la organización de casi dos decenas de panteones, número desconcertantemente elevado. Las lecturas han oscilado entre dos extremos: atribuir una personalísima singularidad a la historia medieval de la que acabó siendo la mayor corona peninsular o, por el contrario, buscar elementos que habilitasen una homologación de fondo entre el caso castellano y otros europeos. Este es el interrogante nuclear: ¿fue Castilla un reino (y más tarde una corona) singular, como pretendió Sánchez Albornoz, o más bien una realidad política equiparable a otras?

En paralelo al debate anterior, numerosos historiadores han sostenido la vocación de subsistencia y prosecución a través de los siglos: desde la hecatombe visigoda hasta la reinstauración de la ley cristiana en la totalidad de la península ibérica ${ }^{3}$. Se ha procurado demostrar que el férreo principio de continuidad histórica fue interpretado como guión -bandera y también línea argumental- por los sucesivos herederos del trono. Y digo trono, en singular, porque en esa lectura, que construyeron

\footnotetext{
${ }^{2}$ A. Dierkens, Quelques réflexions.

${ }^{3}$ Los enterramientos reales como manifestación del poder transmitido al sucesor en E. Mitre, La muerte primera, pp. 27-48, esp. p. 39, en consonancia con las tesis de E. Kantorowicz.
} 
los cronistas del siglo XIII y en la que asientan sus presupuestos distintos historiadores e historiadores del arte ${ }^{4}$, se certifica un encadenamiento progresivo, vertebrado, teleológico y, a la postre, circular: se parte de la enajenada Toledo para regresar a la resarcida Toledo ${ }^{5}$. El trono sucesivamente visigodo, asturiano, leonés y castellano sería así el mismo aunque en cambiantes formatos ${ }^{6}$, en una linealidad en la que el pasado se interpreta como el cúmulo de causalidades que propician que el destino se cumpla en el presente. Como consecuencia lógica de esta perspectiva, no faltan lecturas que en la actualidad siguen reconociendo y reivindicando en la historia medieval castellana (por no extrapolarlo a todo el ámbito hispano) una unidad de destino ${ }^{7}$. Así las cosas, se intenta explicar que los monarcas castellanos no requirieron -como necesidad de estabilidad institucional- que sus ataúdes convergieran en una única necrópolis, como los Capetos y Valois ${ }^{8}$. La prioridad política y religiosa de lograr el desagravio territorial e institucional resultaba más perentoria que la exposición de una línea dinástica ininterrumpida. A fin de cuentas y en última instancia -continúo parafraseando esa perspectiva interpretativa-, la fortaleza de cada rey y de su reinado vendría dada por su cita con el destino histórico antes que por su vinculación con su inmediato predecesor; aunque, claro está, sólo los legitimados podían desempeñar de modo eficaz la misión. Sin menoscabo de esas disquisiciones, a los historiadores nos compete también averiguar por qué la memoria de un reino, como la de una persona, se forja en términos selectivos ${ }^{9}$. Nos atañe esclarecer por qué cada presente dispensó de manera intencional luces y sombras sobre sus pretéritos. Debemos desentrañar por qué un determinado relato histórico podó con estruendosos silencios aquellos acontecimientos o protagonistas que evaluó como ramificaciones infructuosas o contradictorias respecto al tronco del destino.

La ausencia de exequias protocolarias en la realeza castellana y la multiplicidad de recintos cementeriales constituyen dos rasgos sintomáticos del expediente de singularidad política y escenográfica. En esa convicción de que la corona castellana -y sus precedentes históricos- se comportó de manera diferente a otras pero idéntica a sí misma, bajo la batuta del vector de continuidad, han abundado Ruiz, Rucquoi o Menjot $^{10}$ y sus copiosas secuelas historiográficas.

${ }^{4}$ Ayuda a situar la cuestión el análisis de E. Mitre, La muerte del rey, pp. 167-183.

5 T. Ruiz, Une royauté sans sacre, pp. 429-453, esp. p. 432. Sus argumentos han sido ampliamente contestados por J.M. Nieto, La Monarquía bajomedieval Castellana, pp. 1225-1238, entre otros trabajos de este autor. M. Ríos, La Reconquista: ¿una aspiración peninsular?.

${ }^{6}$ Las estructuras gubernativas y los principios políticos de los reyes astures del siglo IX y de los leoneses del X pueden homologarse con facilidad. Es más, se ha llegado a sugerir que no cabe deslindar las monarquías de un lado y del otro de la cordillera cantábrica. C. Estepa, El poder regio y los territorios, pp. 451-467. Ante todo, el magistral estudio de P. Linehan, History and the Historians, pp. 313-505. E. Falque, Lucas de Túy, pp. 151-161. Sitúa el conocimiento y posicionamiento histórico del Tudense en el siglo XIII la tesis de E. Jerez, El Chronicon Mundi, pp. 10-19, pp. 163-179 y esp. pp. 180-197. Valoraciones sobre el principio de continuidad genealógica en G.M. Spiegel, The Past as Text, pp. 99-110.

${ }^{7}$ Ante el peso de esta autoridad historiográfica, P. Linehan, Spain, 1157-1300, esp. Prefacio [trad. española, Barcelona, 2009], que acentúa la fragmentación derivada de la desorganización bélica.

${ }^{8}$ Pero no antes del s. XI, como parece olvidarse a veces. M.E. Prada, J.M. Vidal, La muerte de los reyes de León (siglos X-XI), pp. 239-320, esp. p. 241. Para los panteones merovingios y carolingios R. Alonso, El Panteón de los reyes de Asturias, pp. 37-47. Sus homólogos hispanos en idem, Los enterramientos de los reyes visigodos, pp. 361-375.

9 P. Geary, La mémoire et l'oubli, pp. 171-198.

${ }^{10}$ J. Mattoso, A morte dos reis, pp. 79-95. D. Menjot, Un chrétien qui meurt toujours, pp. $127-$ 138, trabajo en evidente contraposición lingüística y nacional al de R.E. Giesy, Le roi ne meurt jamais.

ANUARIO de Estudios Medievales, 42/2, julio-diciembre 2012, pp. 535-565

ISSN 0066-5061, doi:10.3989/aem.2012.42.2.02 
En estas páginas dejo de lado facetas principales de la muerte regia, desde el lugar del óbito hasta las ceremonias de exequias, examinadas en trabajos de otros autores. Me concentro en los recintos cementeriales del Reino de León desde una perspectiva histórico-artística, a la luz de referencias documentales y huellas murarias. Examino aquí la genealogía arquitectónica y funcional de los panteones de los últimos reyes de León, sus vínculos históricos tanto como sus innovaciones y deslindes de la tradición regia.

\section{LOS PRIMEROS PANTEONES LEONESES: LA CAPITAL REGIA Y SAHAGÚN}

En el seno de Santa María de Oviedo, y una vez concluida su construcción, Alfonso II dispuso un cementerio para sí y, al tiempo, propuso un panteón para sus sucesores, relicario para la futura memoria de su dinastía. Al llevar a cabo la instalación de su sepulcro en un habitáculo hermético, aunque intra ianuae templi, no pudo ni quiso invocar precedentes ${ }^{11}$. Su comportamiento resultó novedoso en el solar ibérico y causó un efecto atrayente en sus sucesores inmediatos e incluso en el primer soberano que fijó su capitalidad (civitas regia) en León, García I $(\dagger 914)^{12}$. Con posterioridad llegó el cuerpo de Alfonso III ${ }^{13}$, muerto en Zamora, trasladado en primera instancia a Astorga y por fin a Oviedo.

Sampiro señaló que Ordoño II, tras ceder buena parte de su palacio leonés a la sede episcopal, sepultus fuit in aula sancte Marie semper viriginis sedis Legionensis ${ }^{14}(† 924)$. No podemos aseverar si el obispo de Astorga pretendió denotar que el cuerpo regio se encontraba -como en Oviedo- "dentro" de ella. En todo caso, al año siguiente su hermano Fruela II (†925) sepultus iusta fratrem suum legioni fuit, según Sampiro en el cálamo del obispo Pelayo.

Palacio y panteón fueron reubicados por Ramiro II ( $† 951)$. Éste sepultus fuit in sarcofago iuxta ecclesiam sancti Salvatoris ad cimiterium quod construxit filie sue Regine domne Geloire ${ }^{15}$. Sampiro atribuye a la infanta Elvira la organización del cementerio en el atrio del monasterio ${ }^{16}$. Sin embargo, es probable que el monarca decidiera reposar en el monasterio de San Salvador de Palat de Rey. Este nuevo camposanto, a diferencia los precedentes, se halla en un cenobio y no en una catedral. La intercesión espiritual sería procurada por las oraciones de las monjas, y no de monachi o socii catedralicios. Además, el sepulcro marmóreo del soberano no quedó albergado por una construcción, sino que se situó en el cementerio sito al cabo del santuario del Salvador.

El tercer cementerio urbano fue promovido por Alfonso V. Los azarosos acontecimientos vividos en la urbe y el reino en la última década del siglo $\mathrm{X}$, así

${ }^{11}$ Cuestiona su supuesto neovisigotismo A.M. Martínez Tejera, La arquitectura alto-medieval. Interpretó la construcción del conjunto ovetense como un aval del continuismo godo, I. Bango, Los reyes y el arte, pp. 19-32. La trama ideológica en T. Deswarte, De la destruction à la restauration.

12 J. Pérez de Urbel, Sampiro, p. 309. J. Mattoso, A morte dos reis, pp. 80-82, interpreta la omisión del lugar de sepelio en las crónicas astures como una falta de anclaje de la permanencia política, lectura que creo rebatible. León desplegó una débil autoafirmación como capital durante los siglos X-XII a decir de P. Linehan, León, ciudad regia, pp. 409-457, esp. 448 y ss. J.M. Ruiz Asencio, La inclusión del Chronicon, pp. 279-286; E. Fernández Vallina, Sampiro y el llamado Silense, p. 51; M. Carriedo, Pelayo Tedóniz, pp. 395-456; F. Prado Vilar, Lacrimae rerum, pp. 195-221.

13 J. Pérez de Urbel, Sampiro (versión pelagiana), p. 308. Cfr. J. Pérez de Urbel, A. González Ruiz-Zorrilla, Historia Silense, p. 152.

${ }^{14}$ J. Pérez de Urbel, Sampiro, p. 318, se refiere en las dos versiones.

15 Ibidem, p. 332, en las dos redacciones.

${ }^{16}$ M. Carriedo, Una reina sin corona en 959-976, pp. 118-137. 
como las mermas y dispersiones que acarrearon, no dejarían de inducirle a orquestar un nuevo mausoleo. Se ha dicho que meditó y consumó la agrupación de las tumbas dispersas de sus antecesores. Sin embargo, hay base para dudar que desplazara algún sepulcro regio del siglo X: de la mención última de Sampiro, más fiable que el Tudense, se infiere que su padre Vermudo II yacía entonces en la catedral de León, aunque sus restos acabaron llegando a San Isidoro ${ }^{17}$. No creo que pueda afirmarse que Alfonso V organizó un panteón para aglutinar a sus predecesores y anclar su memoria en la continuidad del pasado. Antes bien, consideró dónde podían reposar sus huesos y los de sus descendientes, más que los de sus antecesores. En el año 1042, con Fernando I en el trono, en San Juan Bautista de León estarían depositados "sólo" Alfonso V con su mujer Elvira y Vermudo III con la reina Jimena. Además, la obtención de la nueva reliquia del Bautista actuó como polo de atracción y catalizador de amparo terrenal y escatológico. De ese modo, el nuevo locus regi contará con un prestigioso aglutinante espiritual.

Por el momento, nada sabemos de la configuración material de este recinto funerario ni de su ordenación topográfica. A tenor de la instalación cementerial al oeste del templo y ante sus protocolarios ingresos, la historiografía ha querido reconocer una continuidad y actualización del panteón astur, o cuando menos de su ordenación topográfica, de este a oeste: santuario, naves y cementerio privilegiado ${ }^{18}$. Esa sucesión lineal de ámbitos orquestada en Oviedo se reprodujo ciertamente en San Juan Bautista. A pesar de ello, Alfonso V no buscó un subterfugio para introducir el panteón dentro del edificio. Conforme a los cánones visigodos, el cementerio de San Juan se emplazó al exterior, ante las puertas, aunque ignoramos si estuvo descubierto ${ }^{19}$ y iuxta templum, como el de Palat de Rey ${ }^{20}$. En su concreción topográfica, el camposanto de Alfonso V consideró antes el precedente leonés de Palat, con las tumbas en el dextrum, que el ovetense. Los cementerios regios de León de la segunda mitad del siglo X y la primera del XI no responden al planteamiento de Santa María del Rey Casto, cuya virtual ligazón con antecedentes específicos visigodos nos es desconocida ${ }^{21}$. Se puede establecer una prolongación en el reino de León de la organización de recinto funerario a Occidente, pero la solución que contempla la ocupación de un lugar segregado y exógeno se reconoce en León y Sahagún, pero no en el mundo astur. El mausoleo de San Isidoro incrementó su similitud con el de Santa María de Oviedo sólo cuando difirió de su formulación morfológica por asumir el sistema constructivo y el léxico arquitectónico románicos, a partir de 1073 y de la mano de la infanta Urraca. Fue a partir de entonces cuando el recinto funerario quedó materialmente delimitado y cubierto, además de superpuesto por una tribuna de uso regio o principesco ${ }^{22}$.

${ }^{17}$ Además, a fines del siglo XVI, Jerónimo de Llamas, se refiere a la sepultura del rey Vermudo II que "Esta aora en sant Isidro, en la capilla del claustro que llaman de santa Catherina. Está en un lucillo de mármol liso, el 1 de los doce que está en la vanda delantera”. M. Carriedo, Panteones reales leoneses (ss. X-XIII), pp. 8-97, esp. p. 77.

${ }^{18}$ I.G. Bango, El espacio para enterramientos privilegiados, pp. 100-101.

19 No advierto fundamento material para suponer un cerramiento del cementerio Alfonso V, como planteó I.G. Bango, El espacio para enterramientos privilegiados, p. 104. Cfr. G. Boto, Morfogénesis espacial, pp. 151-191, esp. p. 165, n. 77.

${ }^{20}$ Parece factible que Ramiro II dispusiera el cementerio a poniente y sin techar con fábrica. K. Kruger, Fürstengrablegen in Nordspanien, pp. 33-63, esp. pp. 49 y ss. cuestiona los enterramientos sistemáticos a occidente aludiendo a la ocupación alternativa de los claustros como ámbitos cementeriales de laicos. Pero esta fue excepcional. Cfr. G. Boto, Ora et memora, pp. 105-128.

${ }^{21} \mathrm{R}$. Alonso, Los enterramientos de los reyes visigodos, pp. 361-375.

22 Sobre la tribuna de uso regio, T. Martin, Queen as King, pp. 82-83. Esta autora no considera el "Panteón de los Reyes" como un ámbito funerario desde su génesis. Prefiere imaginarlo como un 
Nada indica que el cementerio de Alfonso V alterase su morfología con la reina Sancha: se trataría de un porche cerrado a la ciudad pero abierto a la clausura. Tres rasgos caracterizaron aquel habitáculo: se localizó en las coordenadas ocupadas por los contraábsides ${ }^{23}$, era funcionalmente autónomo aunque estructuralmente adherido a la iglesia y estaba segregado del espacio cultual de las naves por una puerta. Sin embargo, colijo que el parentesco del cementerio leonés y el de Santa María del rey Casto era menor de lo que la historiografía ha reiterado enfáticamente ${ }^{24}$. Aunque compartieron dos factores (la distribución axial de presbiterio, naves, cementerio y la ocupación restringida a miembros de la dinastía regia), difirieron en tres peculiaridades: incorporación vs. segregación en el cuerpo físico del templo; hermetismo vs. permeabilidad de paso; refracción severa al acceso vs. restricción a la comunidad. Con todo, ni en los años de Fernando I ni en los posteriores en que la infanta Urraca efectuará la monumentalización se podía circular indiscriminadamente in cimiterio Sancti Pelagii Legionensi ciuitas (documentación de mediados del siglo XI), in Legionenssy regum ciminterio (preciso enunciado del Silense) o in sepulchris regum (denominación de la Chronica Adefonsi Imperatoris $)^{25}$.

espacio palatino y retrasar su empleo como cementerio a la segunda mitad del siglo XII. En tal caso Fernando I, que se dejó convencer por la reina Sancha para no enterrarse en Arlanza u Oña sino en León, habría aceptado una distancia a la Domus Dei que no mediaba en los cenobios castellanos. Siguiendo con esta paradójica interpretación, la infanta Urraca habría promocionado un programa escultórico y pictórico de intercesión soteriológica para dependencias palatinas en lugar de cementeriales. Distintas evidencias apuntalan la lectura tradicional. En relación con ello, agradezco a la redacción de esta revista que, ya en prensa, me permita añadir, puntualmente, G. Boto, In Legionenssy regum ciminterio, p. 107-119.

${ }^{23}$ En ese idéntico emplazamiento, ¿debe reconocerse una sustitución -o suplantación, incluso- del contraábside por el pórtico, y a la inversa, de éste por aquél, de suerte que las funciones y naturaleza ocupacional de uno fueron transferidas al otro? Esta es la tesis razonada y consolidada de Martínez Tejera y Bango en respectivas intervenciones y publicaciones de inicios de los años 90 del siglo pasado. Desde luego, no nos ha llegado más ejemplo certero de un contraábside funerario que el de Peñalba, salvo que consideremos el habitáculo de Oviedo como un contraábside, lo que me parecería arriesgado y contradictorio.

${ }^{24}$ R. Alonso, Los enterramientos de los reyes de León, § 10. En el pórtico de San Esteban ("Sepultus sancti Stefani pórtico" reza el Initium Regnum Pampilonam) fue enterrado el navarro Sancho Garcés I (905-925). Su hijo y sucesor, García Sánchez I, recibió sepultura (970) "in castro sancti Stefani", identificado como San Esteban de Deio, en Monjardín. Según A. Martínez, El "Pórtico románico”, pp. 191-227, esp. p. 221, ésta es la primera aparición documental del término porticus. Su emplazamiento lateral, exterior y transitable nada tiene que ver con el habitáculo funerario de Santa María del Rey Casto.

${ }^{25}$ J. Pérez de Urbel, A. González Ruiz-Zorrilla, Historia Silense, pp. 197 y ss. El acopio de todas las referencias en M.E. Prada, J. Vidal, La muerte de los reyes de León, p. 258. De particular interés los documentos publicados en J.M. Ruiz, Colección documental del archivo. IV (1032-1109), pp. 278-280, docs. 1084 y 1085. El abad leonés Froilán se denomina de San Pelayo y no de San Juan y San Pelayo en 1052. Resulta sintomático que el "abbas Sancti Pelagii, item cimiterii Legionensis", señale que el cementerio era de San Pelayo, cuando es evidente que se encontraba a los pies de San Juan Bautista, incluso si el prelado interpretaba que ambos templos constituían los dos componentes indisociables y complementarios de una unidad monástica. 


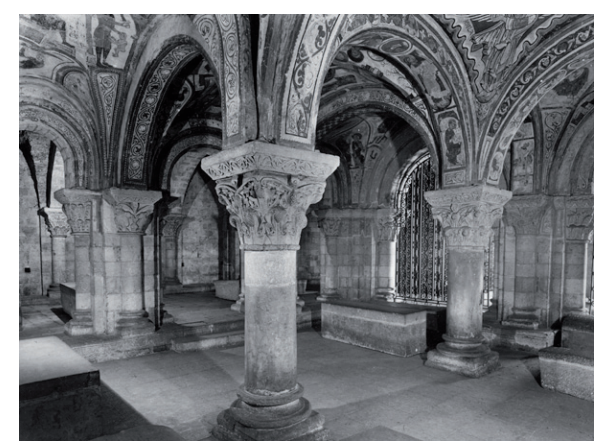

Fig. 1. Cementerio regio de San Isidoro de León.

Como asentó Bango, este recinto nunca fue concebido ni empleado como un westwerk o un macizo occidental al modo germánico o franco, esto es, como acceso principal al templo y en consecuencia abierto y transitable ${ }^{26}$. No parece, que el proyecto cementerial de Sahagún difiriese de esta disposición espacial. Eso, al menos, cabe interpretar a la luz de las fotografías que documentaron las excavaciones del año 1934 a cargo de Alejandro Ferrant ${ }^{27}$.

\section{UN PANTEÓN BAJO LA GLORIA. \\ EL PROYECTO COMPOSTELANO DE FERNANDO II Y SU METAMORFOSIS}

Tras el sepelio de Alfonso VI (†1109) en Sahagún y de Urraca I (†1126) en San Isidoro, concluye la historia de recepción de cuerpos de monarcas reinantes tanto en un cementerio como en otro. En 1127 Alfonso VII prometía a Gelmírez sepultarse en la catedral compostelana, para inaugurar de ese modo un panteón, tan novedoso como su linaje borgoñón. De nuevo en agosto de 1140 y aún en junio de 1141 el Emperador y su esposa hacían oblación de su recién fundada capellanía y su cancillería, al tiempo que concedían ser enterrados en la iglesia del Apóstol, en la que Alfonso Raimúndez había sido bautizado y más tarde educado, como declara sentimentalmente el documento ${ }^{28}$. A pesar de lo que se ha llegado a apuntar, los documentos no permiten concluir que el arzobispo compostelano prometiera a Alfonso VII y a la reina

${ }^{26}$ I.G. Bango, El espacio para enterramientos privilegiados, p. 105.

27 G. Boto, Panteones regios leoneses (1020-1109). Me consta que otros colegas (Julio Vidal y José Luis Senra) se han ocupado de esas mismas fotografías recientemente, pero no puedo valorar sus estudios porque en 2011 aún están en prensa. Será imprescindible atender a sus sugerentes trabajos.

${ }^{28}$ Oblación "de mei corporis et mee coniugis sepultura, quod prefate ecclesie concedo sepeliendum”. S. López Ferreiro, Historia de la Santa A. M. Iglesia, vol. IV, p. 30-32; M. Lucas, La documentación del Tumbo A, pp. 261-263 y 265-267. J. Salazar, La casa del rey, pp. 221-232, señala que el de capellán del Rey, también normalmente su confesor, fue un cargo atribuido a un obispo, de derecho en el Arzobispo de Santiago por privilegio de Alfonso VII en 1140, confirmado por Fernando II en 1158 y de nuevo en 1180. Con alusión a la heráldica temprana, S. Moralejo, La iconografía en el Reino de León, pp. 139-152. Para la contextualización del asunto, D. Nogales, La representación religiosa de la monarquía, pp. 139-162. 
Berenguela que serían enterrados en el interior de la catedral ${ }^{29}$. De cualquier modo, el monarca cumplió parcialmente con lo acordado: concedió a la sede de Santiago la inhumación de su mujer en febrero de 1149 (1148). Pero Alfonso VII faltó a su promesa cuando optó finalmente por la catedral primada toledana $(\dagger 1157)^{30}$. El arzobispo de Toledo ganaba la partida y ese triunfo se acrecentó con la llegada del cadáver del primogénito Sancho III $(† 1158)$ al año siguiente. Al inclinarse por Toledo en detrimento de Santiago, Alfonso VII no sólo reivindicó su preeminencia sobre otros reinos ibéricos. La decisión, además, implicó un vuelco en la jerarquización de los centros políticos y funerarios vinculados con las monarquías leonesa y castellana. Desde entonces, se consideró explícitamente que la autoridad política dispensaba el dominio ideológico además de político sobre el territorio gobernado, como interpreta Guiance. La legitimación -mejor aún que la legitimidad ${ }^{31}$ - marcará un modelo referencial para la descendencia del linaje, en este caso el futuro Sancho IV.

A mediados del siglo XII la sede toledana no era más que una mezquita reconsagrada. Ignoramos su distribución y, por ello, no tenemos la certeza de que las tumbas regias estuviesen en el interior del templo. Acaso ocupaban una capilla aislada o un pórtico. Nada aclara que se dijera en las crónicas alfonsíes que aquel primer destino era un muy onrrado logar. Sólo podemos apuntar un hecho: cuando en 1289 el rey Sancho IV mandó trasladar los cuerpos de Alfonso VII y Sancho III a la recién fundada capilla de la Santa Cruz, al este del altar mayor de la catedral, los sepulcros de ambos se encontraban en la capilla del Santo Espíritu, una capilla perimetral del edificio gótico iniciado en $1221^{32}$.

Fernando II (†1188), en el primer año de su reinado, en 1158, remedó a su padre al confirmar al arzobispo compostelano cancellarie et capellanie ${ }^{33}$. En el compromiso de entrega del cuerpo en 1180 a la sede apostólica ratificó la escribanía y capilla. Fernando II renovaba la opción catedralicia que había quedado arrinconada desde los tiempos de Ordoño II y Vermudo II -sepultados en la sede de León-, y sólo resarcida en los días de Alfonso VII (Toledo) y Doña Berenguela (Compostela). Desde 1157 y hasta los Reyes Católicos, todos los monarcas leoneses y castellanos fueron en-

${ }^{29}$ X. Dectot, Les cimetières aux rois, pp. 55-62, esp. p. 58, sostiene que Alfonso VII fue enterrado dentro de la catedral toledana con dos frágiles argumentos: que le concedieron otro tanto ya en 1140 en Santiago y que requirió a los monjes de Oña en 1137 que trasladaran al interior del templo los cuerpos de Sancho II y de otros personajes. Sin embargo, la comunidad oniense desestimó la solicitud imperial. Cabe inferir que la rígida normativa eclesiástica era estrictamente observada aún en la primera mitad del siglo XII.

${ }^{30}$ S. Vajay, From Alfonso VII to Alfonso X, pp. 366-417.

${ }^{31}$ Discute los procesos de legitimidad y legitimación, I. Alfonso, Judicial Rhetoric and Political Legitimation, pp. 51-88. P. Henriet, Political struggle and the Legitimation, pp. 291-318, argumenta que la legitimación no es, al menos en parte, religiosa; A. Rucquoi niega que lo sea en modo alguno. Además, A. Ellenius, Iconography, propaganda, and legitimation. Especialmente J.M. Nieto, Propaganda and legitimation in Castile, pp. 105-119. Sus fundamentos en los orígenes de la nueva monarquía gala, K.F. Werner, Les sources de la légitimité royale, pp. 49-60. Para el mundo castellano bajomedieval, J.M. Nieto, Les clercs du roi, pp. 297-318; L. Vones, Historiographie et politique, pp. 177-188. En el ámbito aragonés, D.J. Smith, James I and God, pp. 105-119. En el dominio eclesiástico, P. Henry, From Apostle to abbot, pp. 491-505. Desde una perspectiva más amplia, P. Henriet, A la recherche de légitimités chrétiennes. Lecturas neofenomenológicas en A. Cole, D.V. Smith, The legitimacy of the Middle Ages.

${ }^{32}$ F. Gutiérrez, Las empresas artísticas de Sancho IV, pp. 165-166.

33 S. López, Historia de la Santa A. M. Iglesia, pp. 72-74; J. Salazar, La casa del rey, pp. 568-569. 
terrados en distintas y distantes catedrales ${ }^{34}$, salvo cuatro casos que responden a casuísticas diferentes ${ }^{35}$. Optaron también por sepultarse en catedrales la casa navarra desde la segunda mitad del siglo XII y la breve y accidentada dinastía privativa de Mallorca ${ }^{36}$.

No hay ninguna duda de que Fernando II deseó inhumarse en la sede de Compostela, junto a su madre, dando cumplimiento en sus propias carnes a la promesa de su padre. Además de Berenguela, la catedral de Santiago alojaba la tumba en enfeu de Raimundo de Borgoña, raíz de la dinastía. Consta que en la catedral encontró acomodo Fernando Alfónsez (†1214), primogénito muerto prematuramente, y su padre Alfonso IX (†1230). Más tarde llegaría el cuerpo de Juana de Castro (†1374).

El sarcófago de Fernando II, una vez acogido en la sede compostelana en la primavera de 1188 , no sin tensiones entre su heredero y algunos nobles ${ }^{37}$, fue depositado en un lugar ignoto. La noticia de que la capilla de San Lorenzo contuvo los despojos regios desde principios del siglo XIII lleva a identificarla con la capilla de Santa Catalina, habilitada en el extremo noroeste del transepto norte, contigua a la puerta Francígena, por la que ingresaban los peregrinos. Allí mismo desembocó el cuerpo de Alfonso IX en 1230. El testimonio de Lucas de Tuy disipa cualquier especulación: el último rey de León y Galicia fue inhumado junto a su padre, su abuela y su bisabuelo $-\mathrm{y}$, si tomamos en consideración una hipótesis de Moralejo, de su hijo Fernando Alfonso $^{38}$ - en la capilla de Santa Catalina. En 1641 las tumbas fueron trasladadas e instaladas en la capilla de los Reyes, más tarde denominada capilla de las Reliquias, espacio medianero entre la basílica y el Claustro Nuevo ${ }^{39}$. Los debates para llevar a efecto el traslado se habían iniciado ya en 1535.

El 25 de julio de 1180 -festividad del martirio de Santiago- Fernando II, junto con su hijo Alfonso, concedía a la iglesia compostelana su sepultura y la de sus sucesores y con ellas una capellanía y una cancillería regias ${ }^{40}$. El propósito de generar un nuevo panteón dinástico, y no sólo personal, resultaba tan elocuente como deliberado. Tras el óbito de Fernando II, Alfonso IX se preocupó de satisfacer el requerimiento efectuado por su padre hacía ocho años. Maestro Mateo asentaba los dinteles del Pórtico de la Gloria sólo un mes antes de que Alfonso IX depositara en la catedral compostelana el cuerpo de su padre (3 de mayo de 1188).

Graves acontecimientos precedieron a la decisión de aquel 25 de julio. En febrero de ese mismo año de 1180 Fernando II había inhumado a su segunda mujer, Teresa

\footnotetext{
${ }^{34}$ En 1263, un año después de su conquista, Alfonso X erigió en Cádiz una iglesia de la Santa Cruz para preparar su enterramiento. Finalmente se sumó a su padre y madre en la catedral de Sevilla. Sancho IV, cuando aún era infante, solicitó ser inhumado en el convento de San Francisco de Toledo. Después optó por la catedral, acorde con la dignidad regia. F. Gutiérrez, Las empresas artísticas, p. 188. Concuerdo que la presencia en la sede del cuerpo del Emperador debió suponer un argumento de peso.

35 Alfonso VIII, inhumado en Las Huelgas de Burgos, Pedro I arrastrando su mal hado de Montiel a Madrid y disminuido por Enrique II, el piadoso Juan II en la cartuja de Miraflores y el menguado Enrique IV al pie de su madre en Guadalupe, vedadas otras opciones por Isabel I.

${ }^{36}$ G. Boto, Panthéons royaux des cathédrales, pp. 275-310.

${ }^{37}$ R. Sánchez, El entorno imaginario del rey, p. 307.

${ }^{38}$ S. Moralejo, ¿Raimundo de Borgoña, pp. 161-178.

39 A. Morales, Viaje a los reinos de León, pp. 53 y 126-127 alude a la capilla primera en el transepto N: "Mas porque ocupaba y afeaba allí la Iglesia, y tampoco no era un lugar muy honroso, el Emperador que está en el Cielo, dio licencia que se pasasen a la Capilla del Cabildo, que llaman agora de los Reyes". La distribución según Morales: Fernando II a la izquierda, a su lado Alfonso IX, después una reina coronada y un mancebo sin corona; a la derecha del altar Juana de Castro y otras tres anónimas tumbas rasas.

${ }^{40}$ M. Lucas, La documentación del Tumbo A, pp. 307-309. Fecha el documento el 26 de julio, J. González, Regesta de Fernando II, p. 440.
} 
de Lara, en el panteón de San Isidoro de León ${ }^{41}$. Volvió a proporcionar el mismo destino leonés al cuerpo de su hermana Estefanía el 1 de julio de 1180, sólo veinticinco días antes de confirmar su sepultura en Santiago. Los enterramientos de la reina y de la princesa refrendaban el emplazamiento de la capilla real en León, al menos para los miembros femeninos del linaje. Con todo, el propio Fernando II había expresado en marzo de 1169 que San Isidoro ostentaba el privilegio de ser el cementerio $\mathrm{real}^{42}$, y no habrá que pasar por alto que sus vástagos García Fernández $(\dagger 1184)^{43}$, hijo de Urraca López de Haro, y Fernando Fernández (†1187), hijo de Teresa de Lara, también fueron enterrados en San Isidoro. El documento no acredita que el monarca pretendiera revalidar la vigencia del panteón isidoriano con su propia sepultura. Lo que barruntó el rey a partir de aquel 1169 hasta finales de julio de 1180 nunca será discernido. La impresión, no obstante, es que dos muertes tan próximas, en el tiempo y en el ánimo, debieron conmover a Fernando II y apremiarle a corroborar una decisión concluyente sobre el lugar de su mayestático descanso eterno. De modo palmario, deseó reproducir el primer criterio de sus padres, pero sin hacerlo extensivo a su esposa y hermana. Una vez muerto, su primogénito detalló los argumentos genealógicos que sustentaba la decisión: in eodem loco [aecclesia Compostellae] corpori suo eligens sepulturam; et avia ac proavi nostrit ${ }^{44}$.

Fernando II decidió elegir Compostela como lugar de enterramiento conforme a una lógica sentimental y dinástica, logrando la íntima y eterna compañía de su madre $(\dagger 1149)$ y su abuelo paterno (†enero de 1107$)$, en un momento en que ya no podía pretender semejante intimidad con su padre Alfonso $\mathrm{VII}^{45}$. Desde este punto de vista, no se pasará por alto que Fernando II se intitulaba rex hispaniorum hasta el año 1165. Desde entonces el consolidado peso político de su sobrino, Alfonso VIII de Castilla ${ }^{46}$, hizo inviable esa aspiración panhispánica. Fernando II no obviaba que el nuevo panteón monárquico del vecino y litigante reino de Castilla se emplazaba en la catedral de Toledo: allí fueron enterrados Alfonso VII en agosto de 1157 y pocos meses después Sancho III. Si Fernando II buscaba reforzar su posición estratégica y la de su reino leonés también en términos funerarios, verificando él lo que Alfonso VII prometiera en 1127, 1140 y 1141, debía optar indefectiblemente por la sede compostelana, cardinal en León como lo era Toledo en Castilla. Lograba así situar al reino leonés y a su linaje en plano de igualdad con el de Castilla, toda vez que aún faltaba mucho para saber que Alfonso VIII y Leonor Plantagenet acabarían sepultándose en el monasterio cisterciense de Las Huelgas ${ }^{47}$. Fernando II no sólo proclamaba ante los

${ }^{41}$ Sobre la primera esposa, Urraca de Portugal, véase. infra n. 77.

42 J. González, Regesta de Fernando II, p. 407.

${ }^{43}$ M. Carriedo, Panteones reales leoneses (ss. X-XIII), pp. 74-75.

${ }^{44}$ M. Lucas, La documentación del Tumbo A, pp. 330-331. Mayo de 1188. Los términos empleados eran frecuentes en las cancillerías catedralicias: por ejemplo véase el modo de elegir sepultura Enrique de Gante, H. de Gandavo, Opera Omnia, pp. 225 y ss., esp. p. 231.

${ }^{45}$ L. Tuy, Chronicon Mundi. Ab origine, pp. 406 y 425; R. Jiménez de Rada, Historia de Rebus Hispania, VII, c. XXIII, p. 246. R. Menéndez Pidal, Primera Crónica General de España, p. 676.

${ }^{46}$ Es sintomático que ya en 1168, con apenas diez años, Alfonso VIII se identifique en el Fuero de Madrigal del Monte como "Ego Ildefonsus, Dei gratia Hispanorum rex". L. Serrano, El Obispado de Burgos, n. 140. Al final de su vida continuará exhibiendo la misma intitulación. En la donación de Uclés a la orden de Santiago ca. 1210 (Tumbo menor de Castilla, AHN, sig. 1046 B, f. 15r-v) se declara "Dei grati a Yspanorum rex".

${ }^{47}$ M. Shadis, Piety, Poltics and Power, pp. 202-227. R. Sánchez, El 'cementerio real' de Alfonso VIII, pp. 77-109, sitúa en la capilla de Las Claustrillas el primer panteón regio. Contrapone y argumenta la más que presumible funcionalidad de ese recinto, P. Abella, Nuevas pesquisas sobre los orígenes constructivos, pp. 32-61. La custodia de los cuerpos y la memoria de los fundadores de templos en J. Kastner, Historiae fundationum monasteriorum; C. Sauer, Fundatio und Memoria, pp. 89-213. 
súbditos presentes y futuros la legitimidad de su heredero, Alfonso IX ${ }^{48}$. Además, subrayaba sus vínculos preferentes con su predecesor y fundador del linaje imperante en ambos reinos, el conde don Raimundo. Esa inmediatez fue solicitada, según el Tudense, por el propio interesado ${ }^{49}$.

El Tudense detalló que en su tiempo la tumba del borgoñón se hallaba en la capilla de Santa Catalina. López Ferreiro infirió de ello que ése había sido ya su destino inicial ${ }^{50}$. Sin embargo, la historiografía reciente sostiene la disposición de la pretiosam sepulturam -así ponderada por la Historia Compostelana ${ }^{51}-$ en el exterior del templo, y no por la parte de adentro como aventuró López Ferreiro ${ }^{52}$.

Sin referencia documental precisa, Puente Mínguez planteó que el sepulcro del conde se hallaba inicialmente en un arcosolio contiguo a la Puerta Francígena por su lado derecho, visible desde el atrio $^{53}$. Es la hipótesis más plausible. Con la privilegiada adherencia a los quicios del Paraíso se reputaba la memoria del conde por haber obtenido todo el gobierno y todo el derecho en Galicia, palabras que la Compostelana pone en boca de Alfonso VI para reconocerle como fáctico gobernante del territorio galaico ${ }^{54}$. A mayores, la mitra tributaba al conde un justificado agradecimiento como magno benefactor de la sede por haber dispensado a esta el señorío de la ciudad. Resulta inevitable interrogarse por la vigencia aún en 1107 de la vieja restricción del I concilio de Braga (561) que vedaba toda sepultura en suelo sagrado ${ }^{55}$, aunque sin perder de vista que en Saint-Sernin de Toulouse los condes ocupaba ese emplazamiento -si bien en el transepto contrario- en la puerta homónima, como recordó Puente ${ }^{56}$. La localización de la tumba de Raimundo de Borgoña foris portas del transepto constituyó un exótico signo europeísta. Por eso, resulta especialmente significativo que tras su inhumación, el cabildo compostelano asumiera como costumbre visitar solemne y periódicamente el sepulcro, con bendición y responso, en cumplimiento de un itinerario procesional procedente del altar mayor que desembocaría más allá de los umbrales del templo ${ }^{57}$. Gelmírez ofreció hacer extensivo semejante protocolo a su hijo Alfonso VII, cuando éste, con suma devoción, promete el 13 de noviembre de 1127 que entregará su cuerpo a la catedral para ser allí enterrado ${ }^{58}$.

${ }^{48}$ M. Núñez, Muerte coronada, pp. 119-121 reconoce a Raimundo en vez de Fernando Alfonso en el discutible yacente masculino. Así, Alfonso IX habría puesto más empeño en conmemorar a su bisabuelo que a su hijo. Sin embargo, el presunto D. Raimundo carece de atributos que le identifiquen como poderoso en ejercicio y, obviamente, eso plantea una severa objeción.

49 "Obiit apud Beneuentum et in ecclesia sancti Iacobi apostoli circa tumulum matris sue et aui sui comitis Raymundi sepultus est”. L. Tuy, Chronicon Mundi, libro IV, § 81, p. 320.

${ }^{50}$ S. López, Historia de la Santa A. M. Iglesia, vol. III, p. 298.

${ }^{51}$ E. Falque, Historia Compostelana, libro I, cap. XXVII, p. 122.

52 S. López, Historia de la Santa A. M. Iglesia, vol. III, p. 298.

53 J.A. Puente, El sepulcro del conde don Raimundo, pp. 83-95. El muro de cierre románico, explica Puente, una vez forrado por la nueva fachada del hastial N, pudo ser perforado en 1547 para proveer de una sacristía a la capilla de Santa Catalina, intervención que destruyó la parte inferior del arcosolio hasta el extremo de dificultar su reconocimiento como tal.

${ }^{54}$ E. Falque, Historia Compostelana, libro I, cap. XLVI, p. 153.

${ }_{55}$ En el santuario jacobeo, en el periodo prerrománico algunos poderosos lograron inhumarse en unos habitáculos y nártex ante las puertas del templo, pero sin traspasar sus umbrales. I.G. Bango, El espacio para enterramientos privilegiados, p. 96.

56 J.A. Puente, El sepulcro del conde don Raimundo, p. 89.

${ }^{57}$ X. Dectot, El rey muerto y el peregrino, pp. 431-439, esp. p. 433, presumió de que la prolongación de los canónigos hasta el futuro sepulcro del rey implicaba que éste se fuera a disponer indefectiblemente en el interior del templo. Para estos oficios litúrgicos, G. Tellenbach, Die historische Dimension, pp. 200-214.

${ }^{58}$ M. Lucas, La documentación del Tumbo A, pp. 245-247. 
Moralejo consideró que la primera cista condal pudo contar con una cubierta escamada de ascendencia aquitana. La rosca del enfeu presentaba un perfil semicircular convencional que no se corresponde con el arco trilobulado sobre columnas entorchadas que enmarca la representación de Raimundo de Borgoña en el Tumbo A (ca. 1129-1134; f. 28v), caso único en esta galería de retratos ${ }^{59}$. Moralejo advirtió en esta composición el reflejo de elementos presentes en la catedral por partida doble: en el retablo argénteo de Gelmírez en 1135 y en la decoración exterior de la basílica ${ }^{60}$. Ciertamente, la composición se encuentra labrada en el testero y en los perfiles externos de las ventanas del deambulatorio. Que ese arco enmarque y conmemore al conde materialmente alojado en la fábrica catedralicia nada tiene de ilógico porque, de todos los soberanos imaginados en el Tumbo A, sólo él se encontraba bajo sus muros. La miniatura constituye, por tanto, el preciso corolario de la adhesión funeraria y arquitectónica asentada décadas atrás.

Más incertidumbres afectan al sepulcro de Doña Berenguela. Las sucesivas menciones al compromiso funerario de Alfonso VII con la sede apostólica no precisan si los cuerpos regios serían depositados bajo las bóvedas de la iglesia o en algún recinto colindante ${ }^{61}$. El habitáculo hermético de Santa María de Oviedo, el circuito cementerial de Palat o de Oña, los pórticos meridionales de Monjardín o San Millán de la Cogolla (Suso), el panteón en el aula de Santa María de León, los recintos adjuntos de San Isidoro y Sahagún, la habitación individualizada de San Juan de la Peña ${ }^{62}$, la sala capitular de San Pedro el Viejo de Huesca... ofrecen -dentro y fuera del reino de León- soluciones tan plurales que sería gratuito inclinarse por una u otra alternativa sin un fundamento documental. Sólo los cementerios de La Peña o Huesca se habían organizado en un lateral de la iglesia, fuera de sus puertas, como ocurrió en Compostela. El resto de recintos se habilitaron clausurados en el extremo occidental del templo -intra o extra muros, según los casos-, en lo que parece una localización preferente, aunque no creo que se pueda dictaminar como canónica.

El documento que certifica la entrega del cadáver de doña Berenguela no precisa ningún estacionamiento específico ${ }^{63}$. Así, ignoramos el lugar de su sepulcro durante la segunda mitad del siglo XII, como tampoco conocemos la posición del panteón de Alfonso VII y Sancho III en la sala hipóstila de la mezquita aljama cristianizada de Toledo. No hay modo de desentrañar si el Emperador o su esposa, en sus respectivas catedrales de destino, llegaron a quebrantar la secular objeción de enterrarse dentro de la iglesia.

\footnotetext{
${ }^{59}$ M.A. Castiñeiras, Poder, memoria y olvido, pp. 187-196, esp. pp. 191 y 193; R. Sánchez Ameijeiras, Dando forma al tiempo, pp. 61-84, esp. pp. 63-67; idem, Sobre las modalidades y funciones de las imágenes, p. 145. A las razones argüidas para justificar la presencia del conde en el cartulario cabe añadir que en el momento de su redacción aún regía la promesa de Alfonso VII de inhumarse allí, junto a su padre. La solución del arco trilobulado figura ya, medio siglo antes, en el Beato de Saint-Sever (BnF, ms. lat. 8878, f. 2).

${ }^{60}$ S. Moralejo, La miniatura en los Tumbos A y B, pp. 45-62, esp. p. 48. Sobre esta empresa, idem, El patronazgo artístico del arzobispo Gelmírez, pp. 245-272.

${ }^{61}$ A pesar de lo que ha presumido X. Dectot, El rey muerto y el peregrino, esp. p. 433; idem, Les cimetières aux rois et leur évolution en León et en Castille, p. 58.

62 X. Dectot, Las sepulturas de Sancho III y sus herederos, pp. 355-363, esp. p. 357, examina las tensas reivindicaciones de La Peña y Leire, sobre todo después de pasar Nájera al dominio de Castilla.

${ }^{63}$ S. Moralejo, ¿Raimundo de Borgoña $(\dagger 1107)$, n. 13; S. López, Historia de la Santa A. M. Iglesia, IV, p. 238, ap. XVIII. Annales Toledanos I, en H. Flórez, España Sagrada: tomo XXIII, p. 391.
} 
En el año en que murió Doña Berenguela ¿la fábrica catedralicia compostelana había consumado el desarrollo de su estructura subterránea occidental y alzado algo de la fachada occidental ${ }^{64}$ No puede descartarse. Sin embargo, cuando en mayo de 1188 arribó el cadáver de Fernando II, el westwerk del templo ya se encontraba montado hasta la altura de los dinteles de las portadas, empresa que pudo llevarse a cabo merced a la pensión vitalicia concedida por el monarca a Maestro Mateo, jefe de obras asentado en la lonja catedralicia desde hacía algún tiempo ${ }^{65}$. No podemos aseverar cuál fue la localización del sepulcro del rey desde aquel año hasta la instalación en la capilla de San Lorenzo, después de Santa Catalina, donde consta a principios del siglo XIII. Como recuerdó Moralejo, la capilla funeraria regia no quedó institucionalizada hasta la consagración de 1211, cuando los canónigos establecieron capellanía, altar y misa diaria ${ }^{66}$. Resulta plausible que en ese año ya estuviera dispuesto el sarcófago con yacente de bulto ${ }^{67}$.

${ }^{64}$ S. Moralejo, Notas para una revisión, pp. 221-236, esp. pp. 231-236, rechazó que en la cripta hubiera nada anterior a Mateo. Por el contrario, C. Watson, A Reassessment of the Western Parts, pp. 502-521 e idem, The Romanesque Cathedral of Santiago, advierte indicios de que las naves llegaron hasta su último tramo en vida del arzobispo Gelmírez. Recupera, así, viejas tesis de López Ferreiro y Conant. Sobre ellas abunda H. Karge, De Santiago de Compostela a León, pp. 165-196, esp. pp. 182 y ss.; idem, De la portada románica de la Transfiguración, pp. 17-30; idem, Die Kathedrale von Santiago de Compostela, pp. 183-199; idem, Magdeburg, Santiago de Compostela, Toledo, pp. 229-246. Agradezco al Dr. H. Karge que me facilitara estos últimos trabajos.

El debate se ha reabierto y se encuentra sub iudice en la más estricta actualidad. B. Nicolai, K. Rheidt, Der westbau von Santiago de Compostela, pp. 341-352. Un examen arqueológico de las estructuras subterráneas, a pesar de la falta de correspondencias visibles en algunos ángulos, que más abajo detallo y que manifiestan en qué grado la compleja obra mateana se añade y acomoda a la fábrica existente, no tropieza sin embargo con obstáculos que comprometan la congruencia de la construcción desde sus mismos fundamentos. Esta coherencia no excluye la preexistencia de algunos elementos y paramentos en parte sustituidos y en parte asumidos e integrados en el proyecto global concebido y elaborado por Mateo.

65 "Concedo a ti Maestro Mateo, que tienes el primer puesto y la dirección de la obra del mencionado Apóstol [«pro munere dono et concedo tibi magistro Matheo qui operis praefati Apostoli primatum obtines et magisterium»], cada año y en la mitad mía de la moneda de Santiago (...) Este obsequio y don te lo concedo por todo el tiempo de tu vida, para que redunde en mejoría de la obra de Santiago y de tu propia persona, y los que esto vean, cuiden y trabaje con más afán en dicha obra [«hoc donum do tibi omni tempore vitae tuae semper habendum quateuus et operi Sancti Iacobi, et tuae inde personae melius sit et qui viderint preafato operi studiosius invigilent et insistant»]". J. Cean, Diccionario histórico, pp. 97-98; R. Yzquierdo, El Maestro Mateo, pp. 6-9. No reconozco pruebas para asumir que el "santo dos croques" sea una imagen de Fernando II como sugieren C. Rückert, J. Staebel, Der Pórtico de la Gloria, pp. 353-366.

66 "In loco ubi pater meus rex dominus Fernandus bone memorie sepultus est". S. Moralejo, ¿Raimundo de Borgoña (†1107), ns. 17-18.

${ }^{67}$ Como acotó S. Moralejo, Alfonso IX cumplimentó el proyecto. Confirmó el emplazamiento, solicitó el túmulo de Fernando II, la renovación y quizá el traslado del de Doña Berenguela, algo después otro tanto con la tumba de Fernando Alfonso (o Don Raimundo) y, en última instancia, su propio sepulcro. X. Dectot, El rey muerto y el peregrino, p. 434, considera, en cambio, las tapas de Doña Berenguela y de Alfonso IX más tardías, hacia 1240. 


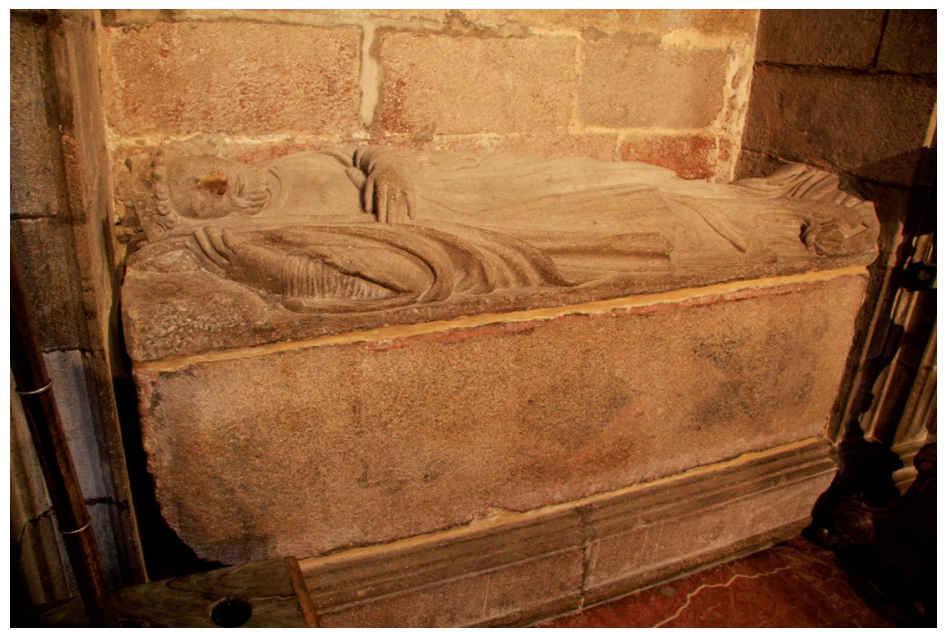

Fig. 2. Tumba y yacente de Fernando II ca 1190-1200.

Sin embargo, desconocemos el destino concedido a los restos del rey durante un par de décadas, desde 1188 hasta 1211.

Al margen de otros eventuales espacios del templo, el nivel inferior del westwerk -denominado hoy cripta o "catedral vieja"- se encontraba ya perfectamente practicable.

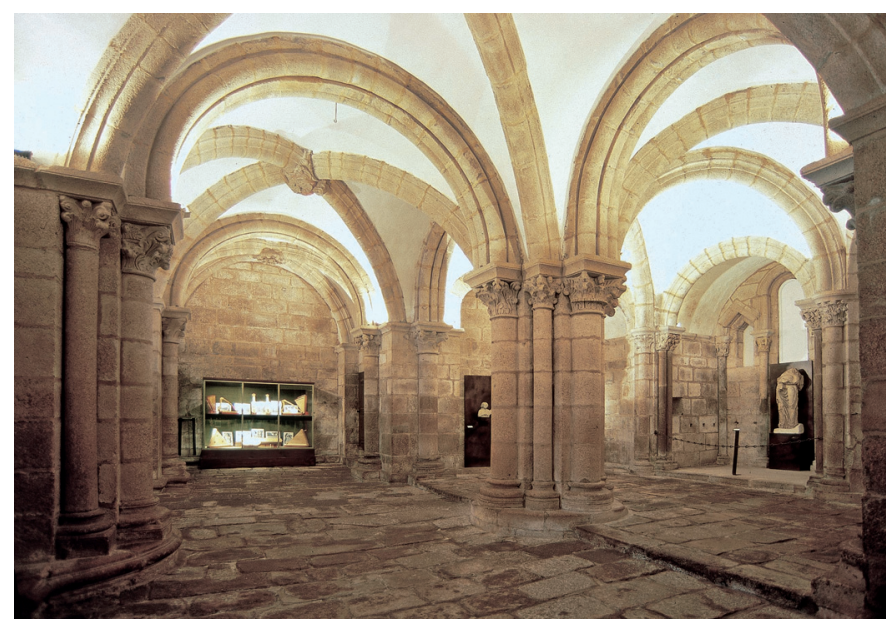

Fig. 3. Cripta del cuerpo occidental de la catedral de Santiago de Compostela.

Mateo había dirigido su construcción desde los fundamentos en un ambicioso y congruente impulso constructivo. A escultores de expediente borgoñón incorporados al primer taller mateano ha atribuido D'Emilio los capiteles y las trazas de 
las bóvedas. Moralejo había cifrado ese mismo origen para las deliciosas claves de la Luna y del Sol ${ }^{68}$. El simbolismo apocalíptico y escatológico de la figuración de las claves -las luminarias de la esfera terrenal y mortal desde la que se accede a la Gloria, vértice de la Jerusalén Celeste denotada en la clave de la tribuna ${ }^{69}$ - encuentra eco y acomodo en la iconografía del recinto arquitectónico, semienterrado y encarado a Occidente. Esta pseudo-cripta resultaba del todo apropiada para acoger sepulcros regios, por su segregación espacial de las naves, su cumplimiento litúrgico y su concordancia con la opción preferente en la heterogénea topografía cementerial asturleonesa. Supone una compleja pero eficaz conjunción de las fórmulas estructurales y funcionales del Panteón de San Isidoro y el mausoleo de Santa María del Rey Casto: invisible desde la nave, como en León o Sahagún, pero orgánicamente dentro del templo, como en Oviedo $^{70}$. Si la cripta ya estaba construida en su mitad oriental en tiempos de Gelmírez, como sostiene Watson ${ }^{71}$, o en su mitad occidental como plantean más recientemente Karge y Rheidt, ese hipogeo habría podido alojar idóneamente a Alfonso VII en 1140. Sin obstáculos y conforme a criterios estimables, pudo contener a Fernando II en 1188. No tengo ninguna duda de que los paramentos y las bóvedas de la cripta (tanto la cabecera-deambulatorio triabsidiada como su transepto) fueron edificados por Mateo y su taller, aunque pudo servirse de algunas estructuras preexistentes ${ }^{72}$.

${ }^{68}$ S. Moralejo, Esculturas compostelanas, pp. 294-310, esp. pp. 300-301; idem, La imagen arquitectónica de la Catedral de Santiago, pp. 37-61, ns. 26-28; J. D'Emilio, Tradición local y aportaciones foráneas, pp. 83-101; R. Sánchez, El entorno imaginario del rey, pp. 312-313.

${ }^{69} \mathrm{~S}$. Moralejo, La imagen arquitectónica, pp. 38 y ss.

${ }^{70}$ R. Yzquierdo, El Maestro Mateo, p. 30 apunta que la estructura pudo haber sido concebida como alojamiento del linaje real, sin remitir a ningún otro autor. Yo mismo ya planteé esa tesis inédita en el otoño de 2006 en el marco de un congreso de la universidad de Lyon-II, que apareció publicada en primavera de 2010.

${ }^{71}$ C. Watson, A Reassessment of the Western Parts, pp. 503-507; B. Nicolai, K. Rheidt, Der westbau von Santiago de Compostela, pp. 341 y ss. M. Castiñeiras, El Maestro Mateo o la unidad de las artes, pp. 187-239, esp. p. 203, detalla los argumentos de estos autores (desvío de la torre N respecto la nave, unidad constructiva en los últimos tramos y la presencia de un pasaje subterráneo) e intenta desarbolarlos con otras evidencias materiales.

${ }^{72} \mathrm{La}$ lectura de paramentos de la "cripta" permite reconocer una unidad constructiva en todo el proyecto. Se constata una irregularidad en la modulación de los sillares en las tres primeras hiladas de la exedra semicircular $\mathrm{N}$, que se prolonga coherentemente y sin alteraciones con el resto de la fábrica a partir de la cuarta hilada. En el pilar esquinero que pasa de la cabecera de la cripta a su 'transepto' sur -en concreto, en el ángulo E de dicho pilar- se evidencia un engatillado (de la segunda a la séptima hilada) de dos episodios constructivos que se cosen en este punto; acomodados y hermanados prosiguen desde la octava hilada, la correspondiente al capitel. No obstante, las incongruencias más notables se advierten en el muro norte del "transepto" norte desde su primera hilada, y en el muro sur del "transepto" sur desde la séptima hilada en el ángulo SE y desde la primera en el ángulo SO. Contra estos paramentos acometen los muros orientales y occidentales de los dos transeptos. Cabría suponer que los muros norte y sur corresponden a una obra previa a Mateo: de hecho, son, respectivamente, las caras de las dos torres de los pies, en su nivel inferior, el que arrancaba del suelo. Interpreto que esas torres ya existían, al menos en su cuerpo inferior, cuando Mateo se hace cargo de las obras catedralicias y, en este punto, coincido con H. Karge, De Santiago de Compostela a León, pp. 184-185. Sin embargo, si existía algún elemento entre las dos torres, Mateo lo eliminó desde la raíz porque el espacio, los lienzos, los pilares y las bóvedas de la cripta responden a un mismo proyecto, mateano y de inspiración borgoñona en múltiples aspectos. Karge sostiene que Mateo "no comenzó su trabajo en un espacio vacío". Yo entiendo que sí fue así. Interpreto que pudo estar vacío porque no hubo vinculación estructural entre las torres antes de 1165; o bien que pudo ser vaciado por Mateo, al suprimir todo rastro de ese eventual elemento intermedio. Por lo demás, el capitel del muro oeste de la 'cripta' parece una pieza instalada en ese lugar y procedente de una cantería cronológicamente anterior. En este extremo disiento de H. Karge, De Santiago de Compostela a León, pp. 183 y 186. Además, que "Pons Sorolla's logitudinal section indicates a dividing wall between the crypt tran- 


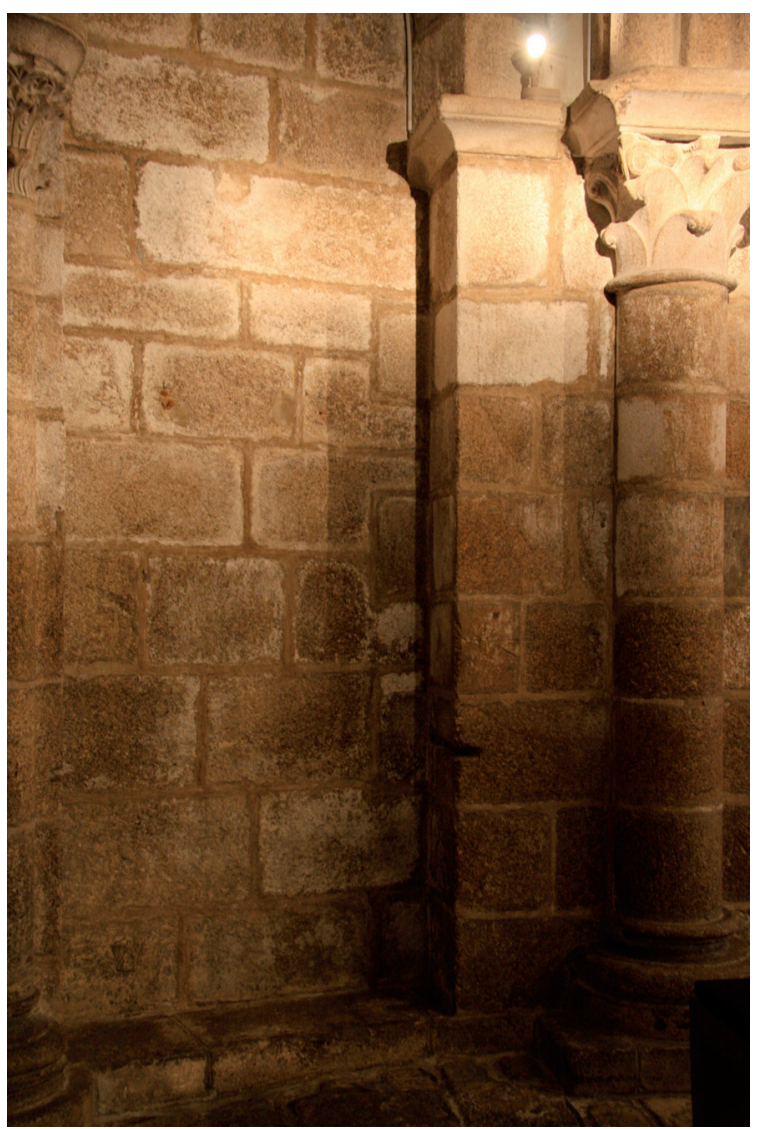

Fig. 4. Muro meridional de la cabecera de la cripta del cuerpo occidental en la catedral compostelana.

sept and the crypt nave" es una apreciación subjetiva, no explícita, de C. Watson, A Reassessment of the Western Parts, p. 503. En los codillos donde esta autora pretende que se sueldan las fábricas gelmiriana y mateana no hay, en cambio, saltos de hiladas ni disfunciones estructurales. A ninguna conclusión cronológica razonada logra llegar cuando contrapone la morfología de las bóvedas y nervaduras en la nave y el transepto de la cripta, salvo atribuir un ánimo arqueologista y nostálgico a Mateo. Sólo el examen del despiece de los elementos y su trabazón con el dovelaje podría resolver esta cuestión. Con todo, reconozco inusual que se descarguen los nervios tanto sobre capiteles como sobre esquinazos.

Por otro lado, en la iglesia, resulta muy reveladora la ininterrupción de las hiladas de los lienzos de los antepenúltimos tramos de las naves laterales y los muros curvos de inicio de las escaleras de descenso hacia la cripta. Este recinto, las escaleras de descenso/ascenso y los últimos tramos de las naves - huelga decir que también el Pórtico- son frutos de un proyecto constructivo conjunto, enormemente complejo y tan ambicioso como original.

Será fundamental conocer la totalidad de los argumentos desplegados por Karge en los distintos trabajos que anuncia y por B. Nicolai sobre el Pórtico de la Gloria a raíz del congreso celebrado recientemente en Berna. 
No obstante, es la intencionalidad y versatilidad funcional del ámbito lo que me importa subrayar. Desde luego, los argumentos esculpidos en capiteles y bóvedas no fueron elegidos ni aleatoria ni autónomamente por Mateo. Subrayan la dimensión semántica de un espacio que no podía ser más propicio para un uso funerario regio: los reyes de la tierra llevarán a ella [a la Ciudad] su gloria (Apocalipsis 21, 24), llevarán la gloria y la honra de las naciones (Apocalipsis 21, 26) a una Ciudad que no tiene necesidad de sol ni de luna que la iluminen (Apocalipsis 21, 23) ${ }^{73}$. Para ingresar en este espacio se discurre bajo dos arcos que presentan en jambas y roscas sendas decoraciones de florones, reiterados en los extremos del transepto de la cripta y en el Pórtico de la Gloria. Habituales en repertorios de ornamentación románica, se emplearon desde la Tardoantigüedad en las cubiertas de recintos cementeriales, como el mausoleo de Gala Placidia, para evocar un firmamento cuajado de estrellas. En esa tesitura, la presencia del sol y la luna son plenamente congruentes. No me extrañaría que en origen las bóvedas de la cripta hubiesen estado cubiertas con la pintura de florones-estrellas, para expresar la bóveda celeste sobre la que se alza la Gloria.

Alfonso IX, responsable de agrupar postmortem la estirpe ${ }^{74}$, ¿llegó a depositar el cuerpo de Fernando II en la cripta desde 1188 hasta 1211? Alfonso IX pudo apreciar sus aptitudes espaciales, escenográficas e ideológicas. No obstante, a la postre prefirió gozar del privilegio de ingresar en el espacio eclesiástico y glorioso, aún cuando se tratara de un exiguo y subrepticio tramo del transepto norte, finalmente dedicado a Santa Catalina. A todas luces esta sobrevenida capilla proporcionaba inferiores cotas de dignitas y decor a los sepulcros regios. Sin embargo, se encontraba más próxima a las reliquias del Apóstol. Por fin, la voluntad de enterrarse ad sanctos -que cultivaron Ordoño II con San Froilán y Alfonso V en relación con la mandíbula del Bautista- se traducía en la orquestación de un panteón regio intus templum, iuxta presbiterium. Esa proximidad física al locus no pudo estrecharse ${ }^{75}$. El cabildo no habría aceptado una interferencia física y funcional entre el altar y el coro pétreo que, en la segunda década del siglo XIII, se encontraba perfectamente organizado. La solución alternativa hubiera sido destinar a panteón una de las capillas perimetrales del deambulatorio o distribuir las tumbas en los umbrales entre girola y presbiterio mayor, como en Saint-Germain-des-Prés. Pero ni una ni otra solución estaba madura en el reino de León por entonces. Los reyes asumieron una posición centrifuga en contraste con el centrípeto cabildo catedralicio. Con todo, se encontraban ya y por siempre dentro de la casa de Dios $^{76}$. Ahora bien, el tráfago ocasionado por los que ingresaban por

${ }^{73}$ Sobre el reflejo de estos pasajes en el sermón "Veneranda Dies" incorporado al Codex Calixtinus, S. Moralejo, La imagen arquitectónica de la Catedral, pp. 52 y ss., notas 23-24.

${ }^{74}$ J. González, Alfonso IX, vol. I, pp. 420-421.

${ }^{75}$ M. Núñez, Muerte coronada, p. 137. Recuérdese las palabras de Ambrosio de Morales, supra.

${ }^{76}$ La organización del panteón regio en el interior de la catedral compostelana encuentra su paralelismo en las tumbas dentro del templo de Poblet, a partir de Alfonso II el Casto (†1196) y definitivamente sólo con Pedro IV. Desde 1196, ningún otro soberano hispano fue sepultado fuera de una iglesia. De hecho, se ocuparon los espacios nucleares, en la nave central junto a o en medio del coro monástico, e incluso el presbiterio. La deposición del sepulcro de Alfonso VIII en el coro de Las Huelgas hacia 1279 (propone una cronología posterior, R. Sánchez, La memoria de un rey victorioso, pp. 289-315), Alfonso VI en el presbiterio de Sahagún después de 1286 y Ordoño II en la catedral de León algo después de 1300. F. Marías, A. Serra, La capilla Albornoz, pp. 33-48, esp. p. 33 estiman que la "capilla real" de la catedral de Córdoba, contigua a la capilla mayor, construida entre 1258 y 1260 por voluntad de Alfonso X, sería el primer caso de una capilla panteón asociada a un presbiterio mayor. Si es existía entonces, esta capilla no fue usada hasta 1312 por Fernando IV y después por Alfonso XI. La otra modalidad castellana consistió en habilitar una capilla contigua al presbiterio 
la puerta Francígena exigió elevar un muro en el margen oriental de la capilla y una puerta o unos barrotes en el ingreso, en el flanco sur.

Alfonso IX encargó la tumba paterna. No sabemos en qué medida adoptó alguna iniciativa para conmemorar a su madre, Urraca de Portugal, a través de un monumento decoroso. A pesar del silencio documental, no debe descartarse una promoción semejante por parte de un monarca particularmente ceremonial ${ }^{77}$.

Hacia 1230 Lucas de Tuy indicó que la tumba de Fernando II se encontraba circa tumulum matris suae, et avi sui comitis Raymundi ${ }^{78}$. El sustantivo tumulum ni acredita ni desmiente la presencia de un yacente. ¿Cómo interpretar el término circa? Si abuelo, madre y nieto compartían un mismo recinto en vecindad habría sido más lógico que el Tudense hubiese recurrido a iuxta, como hizo Jiménez de Rada ${ }^{79}$. Así, ¿las sepulturas de D. Raimundo y Doña Berenguela estaban inmediatas a la de Fernando II? ¿Habían sido introducidas ya en el templo? Stricto sensu y a la luz de la parquedad documental, nada cabe asegurar. Es posible, incluso, que durante algún tiempo

mayor: en Sevilla para Fernando III y Alfonso X, en Toledo para Sancho IV, junto a la nave septentrional, en Oña para Sancho II. En la sede de Palma de Mallorca se ocupó el presbiterio (Jaime II) y se concedió proximidad al altar mayor en Valencia (Jaime III). En la catedral de Pamplona ya sucedía así desde Sancho VI, fórmula reeditada en la colegiata de Roncesvalles para Sancho VII y su esposa. X. Para este caso, Dectot, Las sepulturas de Sancho III, p. 361 y pp. 371-373; idem, El rey muerto y el peregrino, pp. 434-436. La sede iruñesa ha sido la única que en España ha recibido las sepulturas de casi todos los miembros de la dinastía regia de un territorio, de García Ramírez al siglo XV -Champaña y Evreux incluidos-, salvo Sancho VII y los reyes de Francia. X. Dectot, Las sepulturas de Sancho III, p. 360, imagina las tumbas regias en la catedral románica en la entrada del coro, en el mismo lugar que ocuparán, más tarde, en el edificio gótico. Parece que Enrique I estaba enterrado en el coro "en el lugar más distinguido de la catedral" y allí mismo o en las inmediaciones estaría Teobaldo I, según noticias indirectas de ca. 1274. El lugar que se considera panteón es el primer tramo de la nave, donde se instalará más tarde el sepulcro de Carlos III, fuera del coro románico y del gótico, si es que éste no se ha desplazado. En otras catedrales lo habitual fue que las tumbas se situasen dentro del coro, o entre el coro y el altar mayor. La presunción formulada para el caso pamplonés no se compadece con otros ejemplos hispanos ni franceses si pensamos en Saint-Germain-des-Prés o en Fontevrault. Cfr. para ello, E. Carrero, La catedral románica, pp. 856-866, esp. p. 865. En coros monásticos cistercienses (Poblet y Santes Creus) y de predicadores (San Francisco de Barcelona) se emplazarán las sepulturas de los reyes de Aragón, que desdeñaron el potencial atractivo de sus catedrales. No obstante, Juan I estuvo "in itinere" en la sede de Barcelona, y Martín el Humano también. Temporalmente, fueron los canónigos quienes cuidaron de sus cuerpos. F. Español, Els escenaris del rei, pp. 165-167; idem, El Gòtic català, pp. 204-207. Sin embargo, resulta de especial interés el primer sepulcro de Martín el Humano, estudiado ahora por M. Serrano, 'Semblança' de Martí l'Humà. Para el panteón de la casa de Urgell, F. Español, Els comtes d'Urgel, pp. 149-183.

77 Teresa de Lara, segunda esposa de Fernando II, fue inhumada en San Isidoro. La primera, Urraca de Portugal, madre de Alfonso IX, ingresó en La Magdalena de Zamora, sede de la Orden sanjuanista, tras ser anulado su matrimonio en 1175. Allí vivió y murió. Por eso no es desafuero atribuir a Urraca el excelente sepulcro de dama conservado en La Magdalena, como plantea A. Ávila de la Torre, Escultura románica en la ciudad de Zamora, pp. 151-168. La sugerente hipótesis no puede ser acreditada documentalmente. La pieza revela una íntima vinculación con el coro de Compostela. R. Otero, R. Yzquierdo, El coro del Maestro Mateo, consideran que debió ejecutarse hacia 1200 o algo después. El monumento zamorano es coetáneo de los trabajos del panteón compostelano y sus autores poseían el mismo currículum -quizá no el mismo talento- que los escultores mateanos de los yacentes del padre y del hijo (i) de Alfonso IX. p. 183.

${ }^{78}$ L. Tuy, Chronicon Mundi, IV, 81, p. 320; R. Del Arco, Sepulcros de la Casa Real de Castilla,

${ }^{79}$ R. Jiménez, Historia de Rebus Hispania, VII, c. XXIII, p. 246: "et in Ecclesia beati Iacobi est sepultus iuxta avum suum Comitem Raimundum et Imperatricem Berengariam matrem suam". $\mathrm{Y}$ añade que en 1230, tras su muerte, Alfonso IX "in Ecclesia beati Iacobi traditum sepulturae". Ibidem, IX, c. XIV. 
el cuerpo de Fernando II hubiera gozado en solitario de ese privilegio. La capellanía documentada en 1211 atendía a Fernando II. Las cartas regias de 1188, 1192-1195, 1197 y 1204 entresacadas por Moralejo refieren que sólo se rememoraba al rey difunto, enterrado en el recinto cementerial, sin que se especifique de modo inequívoco su emplazamiento. Resultaría insólito que Alfonso IX hubiera dejado de mencionar a su abuela y a su bisabuelo si estos se encontraran iuxta su padre ya en los años de cambio de siglo. Recuérdese que en el documento de 1188 invocado más arriba, se reconoce que los antepasados eligieron sepultarse en la catedral de Compostela, aunque sin detallar dónde. Me temo que el lugar de inhumación de Berenguela y Raimundo no constituía una capilla funeraria ni disponía de un altar propio ni de presbítero adscrito. De otro modo, no hubiera cabido dotar la capellanía ex novo en 1211 . Que el yacente de Berenguela y el de Raimundo (o Fernando Alfonso) admitan ser fechados en el primer cuarto del siglo XIII, o incluso después, permite suponer que los túmulos que han llegado hasta hoy substituyeron a otros previos en el proceso de su traslatio corporis al transepto norte. Moralejo dictaminó que la instalación del altar conllevaría una remodelación del panteón, de la que pudo resultar la renovación de algunos de los sepulcros entonces existentes ${ }^{80}$.

Afirmó el Tudense que Alfonso IX, una vez fallecido, reposaba iuxta patrem suum $^{81}$. Así, después de 1230, sobre el suelo de la exigua capilla se aglomeraban al menos cuatro tumbas: de un bisabuelo a un bisnieto si se cuenta con Raimundo de Borgoña o de una bisabuela a un bisnieto si se trataba de Fernando Alfónsez. Cuatro generaciones, en todo caso, de la dinastía borgoñona de los reyes de León. Por lo demás, en el siglo XIII no consta ya ninguna procesión capitular que vinculara tumba apostólica y tumbas regias. Pero aún así se requería a Santiago su protección sobre los monarcas, garante de la preservación histórica del linaje y, por tanto, de la supervivencia del reino.

\section{TUMBAS INCONCLUSAS. \\ LA NUEVA CORONA Y LA DISCRIMINACIÓN DE LOS PRETÉRITOS PERFECTOS}

A lo largo de más de tres siglos el Reino de León no conoció una tipología única de cementerio regio, aunque la definición de un espacio a occidente de las naves constituyó una fórmula reiteradamente interpretada. Tampoco se recurrió siempre al mismo tipo de establecimientos religiosos ni se organizó un único panteón en una misma población. Ni en León ni en Castilla fraguó el intento de constituir una necrópolis regia predilecta y de obligado cumplimiento a la manera de Saint-Denis, Westminster o Poblet ${ }^{82}$. Si Toledo no logró ser Saint-Denis, León ni siquiera insinuó un

${ }^{80}$ Cabe que todo el sepulcro fuera nuevo o que en el traspaso se reaprovecharan las cajas primitivas y sólo se hicieran ex novo las tapas con yacente. Ambas opciones son posibles si consideramos los casos requeridos por Sancho IV: en su manda de otorgar mejor destino a las tumbas del atrio de Oña, cuerpos y sepulcros ya existentes fueron llevados a la capilla de Santa María (J.L. Senra, Ben per está aos reis, pp. 141-163, esp. pp. 149 y ss.), pero en Sahagún el traspaso de Alfonso VI con sus esposas al presbiterio del monasterio comportó la labra de cistas nuevas (C. Rosell, Crónica de los reyes de Castilla, I, pp. 73-74). Se ignora cuál de las dos opciones se observó en la capilla de la Santa Cruz de la catedral de Toledo con las tumbas de Alfonso VII y Sancho III. F. Gutiérrez, Las empresas artísticas de Sancho IV, p. 182.

${ }^{81}$ L. Tuy, Chronicon Mundi, (E. Falque), IV, 98, p. 338: “in ecclesia beati Iacobi apostoli iuxta patrem suum est honorifice tumulatus".

${ }^{82}$ A. Guiance, Los discursos sobre la muerte, p. 309 y pp. 314-315. En la dispersión por Sevilla, Toledo, Córdoba, Granada... A. Rucquoi, De los reyes que no son taumaturgos, pp. 163-186, esp. 
interés por seguir cumpliendo las funciones de Reims, marco de coronación de reyes $\mathrm{y}$, en monopolio, de emperadores.

Desde el Tumbo A, si no antes, se ordena la retahíla de reyes con la atribución de ordinales. La cronística posterior puso el énfasis no sólo en esa sucesión y prolongación, sino también en la aspiración de restablecer la Christianitas ultrajada en la desarbolada Hispania. Por encima de los reinados particulares, la empresa regia castellana (es decir, sucesivamente astur, leonesa y castellana) se reconoce bajo el prisma de un imperativo político predeterminado: la misión histórica multisecular de recuperar el solar hispánico en toda su extensión, cumplida según el tiempo disponible, las circunstancias vigentes y la distinta urgencia. Esta premisa conformaría uno de los vectores nucleares del gobierno de cada uno de los reyes. Mientras continuara en activo el objetivo de avanzar en el restablecimiento del territorio y la defensa e incremento de las fronteras, la multiplicación de cementerios regios no supondría una objeción al ejercicio y mantenimiento del gobierno regio. Dentro del espacio del reino, cada monarca promocionó el centro urbano y espiritual más provechoso para reivindicar un papel específico en la historia. Desde ese centro, manifestó una vinculación con determinados antecesores, con la actualidad de los poderes eclesiásticos y con la prolongación del gobierno. Para los reyes de Castilla y de León, y desde 1230, de Castilla y León unidos, el solar de su reino constituía un espacio histórico flexible. Esta interpretación de los siglos y de las estirpes ha llevado a justificar la dispersión geográfica de los panteones.

Alfonso X atribuyó a los monarcas, de Castilla como de otros reinos de la Cristiandad, el trascendente papel de vicarios de la Divinidad ${ }^{83}$. Esa competencia, extensible a todas las casas reinantes, fue asumida como compromiso inalienable: el rey continúa siendo un miles christi sin necesidad de acudir a los Santos Lugares. Ese mito cronístico e historiográfico de que la misión del monarca "castellano" (reitero: en realidad astur, leonés y castellano) se cifraba en la supervivencia y expansión de su reino actual y el reencuentro con el pasado godo desmantelado ha inoculado la interpretación irrevocable de la historia hispana (es decir, vectorialmente castellana) ${ }^{84}$ como continuidad in terminis et in re. Desde esta perspectiva, cualquier monarca, en el momento en que recibe el gobierno en calidad de delegado terrenal de Dios, adquiere sus mejores virtudes y asume el verdadero alcance de su misión gubernativa y divinal. A su muerte reintegrará su sabiduría a Dios, quien justifica los logros militares, espirituales y políticos ${ }^{85}$. No hay indicios para suponer que se confería una dimensión

pp. 181 y ss., reconoce toda la Península como un panteón, "la última manifestación quizás de un poder concebido como imperium, identificación entre el que ejerció ese poder y el espacio sobre el que lo ejerció". A su juicio, el linaje de monarcas castellanos no necesitaba reafirmarse a través de una perpetuada asistencia a un mausoleo calificable de nacional. Sólo algunos Trastámaras, quizá por su origen espurio, mostraron interés en construir una "certaine image de la continuité royale". D. Menjot, Un chrétien qui meurt toujours, p. 138.

83 "Vicarios de Dios son los Reyes cada uno en su reyno, puestos sobre las gentes para mantenerlas en justicia e en verdad quanto en lo temporal, bien assí como el Emperador en su imperio. Esto se muestra complidamente en dos maneras. La primer dellas es spiritual, segund lo mostraron los profetas e los santos (...). La otra es, segund natura, assi como mostraron los omes sabios que fueron conocedores de las cosas naturalmente. E los santos dixeron que el Rey es puesto en la tierra en lugar de Dios, para cumplir con la justicia”. Alfonso X, Las siete Partidas, Partida II, tit. I, ley V, f. 14.

${ }^{84}$ P. Linehan, History and the Historians, pp. 463-505.

${ }^{85}$ F. Rico, Alfonso el Sabio y la "General Estoria", p. 130: "conuyene que todo omne que quisiere alguna buena obra començar e seguir e acabar bien, que la comiençe en el nombre de Dios”, y aún que "es manifiesto e connosçido que los saberes son de Dios e non d'otre, e por él son connosçidos e él por ellos”. A. Rucquoi, El rey sabio, pp. 77-87, esp. p. 81. Los perfiles de la ideología política en 
sacra y trascendente al rey, y no es menos dudoso que la poseyera apotropaica, en tanto que presuntos protectores de su reino desde el Más Allá ${ }^{86}$. En el intento de fijar la constancia de la autoridad real y dotarla de una dimensión intemporal se solidificó la unión entre el poder temporal y el religioso, o por mejor decir eclesiástico, y ello a través de distintas fórmulas. La más efectiva, al tiempo que efectista, resultó la de soterrar a los reyes junto a obispos ${ }^{87}$.

Estimo que los panteones plantearon una suerte de balance historiográfico de las tareas y de la piedad de los reyes sepultados. Explícitamente, atestiguan el cuidado de súbditos y descendientes en perpetuar o rehabilitar la memoria del soberano, contrastándola con el trasfondo de la conservación y expansión del reino.

En León, hasta Alfonso IX, los reyes se preocuparon de la dignificación de sus tumbas o de las de sus padres. Él inauguró el interés por los antecesores de segunda o tercera generación. ¿Quién encargó su sepulcro? ¿Lo dejó ya realizado él mismo antes de 1230, como apuntó Moralejo? Si es posterior, como sugiere Dectot, habría sido encomendado por el colegio catedralicio, acaso en la prelatura del arzobispo Bernardo II (1224-1237). Fernando III, pese a figurar en el Tumbo A, no desplegó ninguna iniciativa en relación con el túmulo y la memoria de su padre. Alfonso X sí se ocupó del sepulcro de Fernando III y de Beatriz de Suabia ${ }^{88}$. En realidad, el Sabio llevó a cabo una campaña de rehabilitación de la memoria de algunos gobernantes y héroes de su reino: en 1270 mandó llevar los cuerpos de Pelayo y Gaudiosa de Santa Eulalia de Abamia (Cangas de Onís) a Covadonga, en 1272 resarció la tumba del Cid en Cardeña, ese mismo año hizo otro tanto con el pretendido enterramiento de Wamba en Pampliega, en 1274 honró el sepulcro de Fernán González en Arlanza y quizá en 1279 incentivó la ubicación de los sarcófagos de Alfonso VIII y Leonor Plantagenet en la nave mayor de Las Huelgas ${ }^{89}$. Sancho IV prolongó este programa político-memorialista. En 1286, el Bravo procuró el ingreso de los sepulcros de Sancho II y de los condes de Castilla en la capilla de Nuestra Señora de la iglesia de Oña, dos meses después la instalación de Alfonso VI y sus mujeres en el presbiterio de Sahagún y en 1289 el traslado de Alfonso VII, Sancho III y Sancho II de Portugal desde la capilla del Santo Espíritu a la capilla de la Santa Cruz en la catedral de Toledo. Además, promovió el monumento de su padre en la catedral de Sevilla, inmediato a los de sus abuelos ${ }^{90}$. Entre tanto, durante esas décadas, la tumba de Ordoño II se guarecía en la catedral de León sin pena y desde luego sin gloria. Mal se compadece esos cuidados castellanos con la enfática afirmación de Sancho el Bravo que señaladamente essa eglesia [la catedral de León] es nuestra ffechura e delos Reys onde nos uenymos. El

la corte del Sabio son inequívocos: "por el gran bien, e la grand honra que del recibieron ca segund dixeron los sabios e los santos: los que mayores grandezas e mayores dones reciben de nuestro Señor, mas le son tenudos de seguir e loar que los otros". Alfonso X, Las siete Partidas, Partida II, tit. II, ley IV. M.A. Rodríguez, El paradigma de los Reyes Sabios, pp. 757-765. Para Lucas de Tuy el rey adquiere la sabiduría cuando atiende a los verdaderos sabios, los obispos. Jiménez de Rada fundamentó la realeza a partir de criterios políticos sapenciales.

${ }^{86}$ A. Guiance, Los discursos sobre la muerte, pp. 281-289.

87 J. Mattoso, O poder e a morte, pp. 395-427, esp. pp. 399 y ss. En la sede leonesa, en los albores del siglo XIV el sepulcro de Ordoño II quedó ubicado en medio de un panteón episcopal; en la primera mitad del XV, su cuerpo quedó adherido al de un obispo santo. G. Boto, Sobre reyes y tumbas, pp. 305-365, esp. p. 358. M. Gómez, Sepulcro de Ordoño II. Con desconcertantes carencias bibliográficas, X. Dectot, Les tombeaux des familles royales, pp. 96-98.

${ }_{88}$ J. Martínez, La primera escultura funeraria gótica, pp. 111-129, esp. pp. 118-122; R. Alonso, De Carlomagno al Cid, pp. 469-488.

${ }^{89} \mathrm{R}$. Alonso, Los enterramientos de los reyes de León y Castilla, pp. 31-34.

${ }^{90}$ G. Boto, Sobre reyes y tumbas, pp. 334-335, con la bibliografía correspondiente. 
Bravo nunca se interesó por los monarcas leoneses y asturianos, con la salvedad del conquistador de Toledo, visto así como un conspicuo castellano ${ }^{91}$. Los que detentan la autoridad política en el presente deciden siempre qué futuro tendrá el pasado. Determinan incluso qué segmento del pasado debe adquirir preeminencia en el futuro. Toda interpretación de la historia y de los pasados concéntricos se traduce en la concesión de luces sobre unos rostros y sombras sobre otros ${ }^{92}$.

La tumba de Ordoño II fue realizada a partir de 1300 por parte de cabildo y mitra.

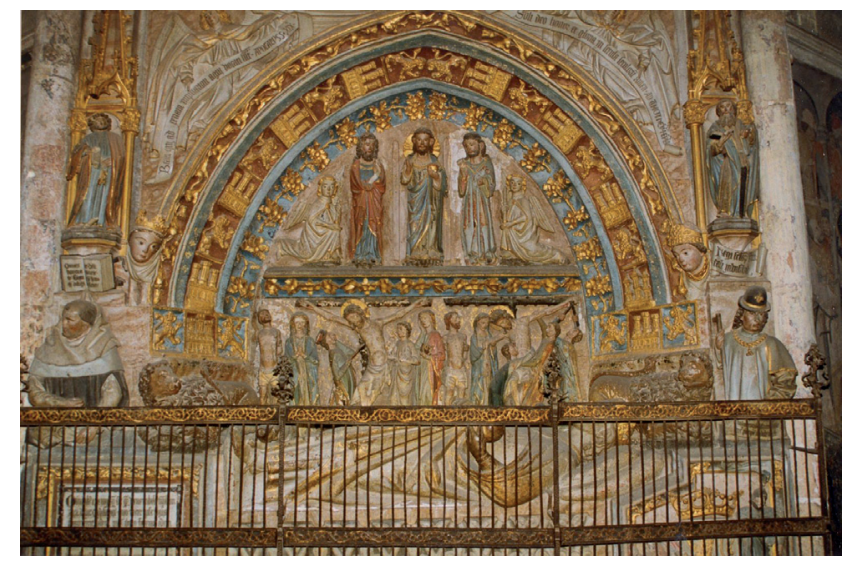

Fig. 5. Catedral de León, Sepulcro de Ordoño II.

Partes esculpidas ca. 1300.

Los mismos promotores entiendo que tuvo el sarcófago de Alfonso IX en Compostela. Unas décadas antes, corroboramos esa misma actitud en los canónigos de San Isidoro. El programa epigráfico y figurativo de las laudes sepulcrales isidorianas revela su ejecución en la segunda o tercera década del siglo XIII, mucho tiempo después del fallecimiento de los representados ${ }^{93}$. Epitafios y retratos pretendieron compensar la desatención de Alfonso IX -concentrado en la catedral compostelana- y subrayar el prestigio y prerrogativas de San Isidoro, como ha apuntado Suárez.

Cuando las preferencias políticas basculaban hacia otras latitudes, hombres de iglesia del exhausto reino de León resguardaron la memoria de sus monarcas, en León o en Compostela. Los reyes de la corona unificada de Castilla y León habían puesto rumbo a un futuro que enhebraba la historia desde un tronco privilegiado del pasado. Se leyó que el reino había militado desde Covadonga en la constancia ininterrumpida, por encima de las transformaciones y sin conceder

${ }^{91}$ Ibidem, p. 336.

${ }^{92}$ Atinadamente sintetiza X. Dectot, Tombeaux et pouvoir royal dans le León, pp. 81-96, esp. p. 92: " un cimetière royal (...) continue-t-il à recevoir l'attention des souverains, qui lui manifestent leur attachement par des dons et, surtout, peuvent y revoir l'ordonnancement ou en modifier les tombes afin d'accorder le message historique dont elles sont porteuses à la vision historique que son entourage ou lui veulent transmettre".

${ }_{93}$ A. Suárez, ¿Del pergamino a la piedra?, pp. 365-415, esp. pp. 381 y ss. R. Sánchez, The Eventful Life of the Royal Tombs, pp. 479-520. 
capacidades tergiversadoras a las mudanzas. Dictaminada la prolongación de un proceso multisecular, cronistas e historiadores infirieron una tesis luego convertida en categoría: la historia de los reyes de Hispania visigoda-Castilla-Hispania sería preceptivamente continuista. Estipulada como una cardinal vocación hereditaria, la continuidad no sólo pretendería robustecer la legitimidad: se advirtió como un principio programático y se encareció como un modo deliberado de comprender el devenir de la Corona. Aun hoy no faltan historiadores que suscriben semejante proposición teleológica. En el Reino de León, los responsables de los sucesivos cementerios procuraron por la memoria histórica por encima de las selectivas memorias políticas. También allí, la vinculación de los reyes a las reliquias santas favoreció la intercesión espiritual y, al tiempo, el desarrollo emotivo de una veneración de los cuerpos regios $^{94}$.

Para concluir ¿cuándo y por qué ingresaron los cuerpos de los reyes dentro del cuerpo del templo? De creer al obispo Pelayo de Oviedo, esa admisión se efectuó por primera vez en Santa María de Oviedo en torno al año 995, motivado por un presuroso traslado desde León y una apremiante falta de espacio en el habitáculo funerario preexistente. Esa disposición persistió durante décadas, al menos. Los reyes enterrados en Palat estaban fuera y los de San Isidoro o Sahagún también; al exterior estuvieron los sepulcros regio y condales de Oña hasta que se les permitió ingresar en templo, no antes de fines del siglo XIII. Creo factible que la 'cripta' compostelana hubiese sido concebida como lugar de descanso eterno para los monarcas. Se trata de un ámbito segregado, pero interno, como la cripta de Montearagón ${ }^{95}$. A la postre, en Compostela la capilla de Santa Catalina se organiza como un espacio acotado situado "dentro", diverso del recinto ovetense sólo en su localización: en el transepto en lugar del hastial de poniente. Desde mediados del siglo XIII, junto al presbiterio de la catedral de Sevilla se habilitó la capilla destinada a Fernando III, esposa e hijo; y otro tanto se dispuso con la de Sancho IV en Toledo. Ambas adquirían una posición privilegiada, pero resultaba incuestionable que se trataba de ámbitos clausurados. Esa misma naturaleza privada caracteriza el panteón de Fernando IV y Alfonso XI en la cripta y el piso, respectivamente, de la Capilla Real de la mezquita de Córdoba. ¿Y qué decir del primer cementerio de los Trastámara en Toledo sino su acusada analogía con el ovetense de Alfonso II? Así, ¿realmente cabe sostener una evolución en la continuidad o un continuismo político? Sólo desde un ánimo interesado en reconocer alineaciones y progresos unidireccionales, partiendo de la tradición, se puede entender el modo en que ha sido valorado el papel de cada cementerio en esa historia regia. Sólo desde ese prisma se advierte el tibio interés por contrastar esas soluciones poliédricas, semejantes y disímiles entre sí, con las ofrecidas desde otras coronas peninsulares.

\footnotetext{
94 Justifica la discutible sacralidad de la monarquía, a partir del siglo XIII, O. Pérez, Quando rey perdemos nunq[u]a bien nos fallamos, pp. 379-394.

95 En la sacristía contigua al presbiterio del templo canonical de Montearagón debió situarse la primera tumba de Sancho Ramírez, antes de su traslado a San Juan de La Peña. R. Del Arco, Sepulcros de la casa real de Aragón, p. 132, toma la noticia del Padre Ramón de Huesca (1797), sin documentación acreditativa. Más significativo resulta que en la cripta de Montearagón se situara y permaneciera el sepulcro labrado y volumétrico -no liso ni inhumado, como los de sus predecesoresde Alfonso I el Batallador. Ibidem, p. 142.
} 


\section{BIBLIOGRAFÍA CITADA}

Abella Villar, Pablo, Nuevas pesquisas sobre los orígenes constructivos de Santa María la Real de Las Huelgas de Burgos, "Codex Aquilarensis" 24 (2008), pp. 32-61.

Alfonso, Isabel, Judicial Rhetoric and Political Legitimation in Medieval León-Castile, en Alfonso, I.; Kennedy, H.; Escalona, J. (eds.), Building Legitimacy. Political Discourses and Forms of Legitimacy in Medieval Societies, Leiden - Boston, Brill, 2004, pp. 51-88.

Alfonso X, Las siete Partidas, G. Martínez Díez (ed.), Valladolid, Lex Nova, 1988, 2 vols.

Alonso Álvarez, Raquel, De Carlomagno al Cid: la memoria de Fernando III en la Capilla Real de Sevilla, en Fernando III y su tiempo (1201-1252): VIII Congreso de Estudios Medievales, Ávila, Fundación Sánchez Albornoz, 2003, pp. 469-488.

Alonso Álvarez, Raquel, El Panteón de los reyes de Asturias. Modelos ideológicos, en Modelos, intercambios y recepción artística: de las rutas marítimas a la navegación en red, Málaga, Ministerio de Educación, Cultura y Deportes, 2005, vol. I, pp. 37-47.

Alonso Álvarez, Raquel, Los enterramientos de los reyes de León y Castilla hasta Sancho IV. Continuidad dinástica y memoria regia, "e-Spania" 3 (2007). http://e-spania.revues.org/109 [consulta: 15/03/2012].

Alonso Álvarez, Raquel, Los enterramientos de los reyes visigodos, en IX Congreso de Estudios Medievales: Fundamentos medievales de los particularismos hispánicos, Ávila, Fundación Sánchez Albornoz, 2005, pp. 361-375.

Ávila de la Torre, Álvaro, Escultura románica en la ciudad de Zamora, Zamora, Instituto de estudios zamoranos Florián de Ocampo - Diputación de Zamora, 2000.

Bango, Isidro G., El espacio para enterramientos privilegiados en la arquitectura medieval española, "Anuario del Departamento de Historia y Teoría del Arte" 4 (1992), pp. 93-132.

Bango, Isidro G., Los reyes y el arte durante la Alta Edad Media. Leovigildo y Alfonso II y el arte oficial, "Lecturas de Historia del Arte" 3 (1992), pp. 19-32.

Boto, Gerardo, Sobre reyes y tumbas en la catedral de León. Discursos visuales de poder político y honra sacra, en Yarza, J.; Herráez, M.; Boto, G. (eds.), La Catedral de León en la Edad Media. Congreso Internacional. Actas, León, Universidad de León, 2004, pp. 305-365.

Boto, Gerardo, Morfogénesis espacial de las primeras arquitecturas de San Isidoro. Vestigios de la memoria dinástica leonesa, en Huerta Huerta, Pedro Luis (coord.), Siete Maravillas del románico español, Aguilar de Campoo, Fundación Santa María la Real, 2009, pp. 151-191.

Boto, Gerardo, "In Legionenssy regum ciminterio". La construcción del cuerpo occidental de San Isidoro de León y el amparo de los invitados a la Cena del Señor, en Huerta Huerta, Pedro Luis (coord.), Monumentos singulares del románico. Nuevas lecturas sobre formas y usos, Aguilar de Campoo, Fundación Santa María la Real, 2012, pp. 91-135

Boto, Gerardo, Ora et memora. Il chiostro di San Domenico di Silos: castellum, paradisum, monumentum, en Quintavalle, A. (coord.), Medioevo: Memoria e Immagine, Milán, Electa, 2009, pp. 105-128.

Boto, Gerardo, Panthéons royaux des cathédrales de Saint-Jacques-de-Compostelle et de Palma de Majorque. À la recherche d'un espace funéraire qui n'a jamais été utilisé, en Baud, A. (ed.), Espace ecclésial et liturgie au Moyen 
Age, actes du colloque international réuni en novembre 2006 à Nantua, Ain, Lyon, Maison de l'Orient et de la Méditerranée - Jean Pouilloux, 2010, pp. 275-310.

Boto, Gerardo, Panteones regios leoneses (1020-1109). Construcción del relato dinástico y salvaguarda de sus postrinerías (en prensa).

Carrero, Eduardo, La catedral románica. Hacia una interpretación funcional, en Bango, I.G. (dir.), La Edad de un Reyno. Las encrucijadas de la diócesis y la corona de Pamplona, Pamplona, Fundación para la Conservación del Patrimonio Histórico de Navarra, 2006, pp. 856-866.

Carrero, Eduardo, El confuso recuerdo de la memoria, en Bango, I.G. (dir.), Maravillas de la España Medieval. Tesoro Sagrado y Monarquía, León, Junta de Castilla y León, 2001, pp. 85-93.

Carriedo Tejedo, Manuel, Una reina sin corona en 959-976. La infanta Elvira, hija de Ramiro II, "Tierras de León” 49/113 (2001), pp. 118-137.

Carriedo Tejedo, Manuel, Panteones reales leoneses (ss. X-XIII), en Prada Marcos, M.E. (dir.), Estudio Antropológico del Panteón Real de San Isidoro de León, León, 2006, vol. I, pp. 8-97 (inédito).

Carriedo Tejedo, Manuel, Pelayo Tedóniz, obispo de León (1065-1085 y 1086-1087): ¿Autor de la Historia Silense?, en Fernández Catón, J.M. (ed.), Monarquía y sociedad en el Reino de León: de Alfonso III a Alfonso VII, León, Centro de Estudios e Investigación "San Isidoro" - Caja España de Inversiones Archivo Histórico Diocesano 2007, vol. II, pp. 395-456.

Castiñeiras, Manuel A., Poder, memoria y olvido: la galería de retratos regios en el Tumbo A de la catedral de Santiago (1129-1134), "Quintana" 1 (2002), pp. 187-196.

Castiñeiras, Manuel A., El Maestro Mateo o la unidad de las artes, en Maestros del románico en el Camino de Santiago, Aguilar de Campoo, Fundación Santa María la Real, 2010, pp. 187-239.

Cean Bermúdez, Juan A., Diccionario histórico de los más ilustres profesores de las bellas artes en España, vol. III, Madrid, Reales Academias de Bellas Artes de San Fernando y de la historia, 1800.

Cole, A.; Smith, D.V. (eds.), The legitimacy of the Middle Ages: on the unwritten history of theory, Durham, Duke University Press, 2010.

D'Emilio, James, Tradición local y aportaciones foráneas en la escultura románica tardía: Compostela, Lugo y Carrión, en Actas. Simposio Internacional sobre: 'O Pórtico da Gloria e a Arte do seu Tempo, Santiago de Compostela, Xunta de Galicia, 1992, pp. 83-101.

Dectot, Xavier, El rey muerto y el peregrino. Estudio sobre las tentativas de recuperación de los flujos de peregrinación en beneficio de la memoria dinástica de parte de los reyes ibéricos (siglos XI-XIII), en V Congreso de Arqueología Medieval Española: actas, Valladolid, Junta de Castilla y León. Consejería de Educación y Cultura, 2001, vol. I, pp. 431-440.

Dectot, Xavier, Les cimetières aux rois et leur évolution en León et en Castille du XIe au XIIIe siècle, "Hortus Artium Medievalium" 10 (2004), pp. 55-62.

Dectot, Xavier, Tombeaux et pouvoir royal dans le León autour de l'an mil, en Deswarte, Th.; Senac, Ph. (dirs.), Guerre, pouvoirs et idéologies dans l'Espagne chrétienne aux alentours de l'an mil, Turnhout, Brepols, 2005, pp. 81-96.

Dectot, Xavier, Las sepulturas de Sancho III y sus herederos, en Bango, I.G. (dir.), La Edad de un Reyno. Las encrucijadas de la diócesis y la corona de Pamplo$n a$, Pamplona, Fundación para la Conservación del Patrimonio Histórico de Navarra, 2006, pp. 355-363. 
Dectot, Xavier, Les tombeaux des familles royales de la péninsule ibérique au Moyen Age, Turnhout, Brepols, 2009.

Del Arco, Ricardo, Sepulcros de la casa real de Aragón, Madrid, Instituto Jerón, 1945.

Del Arco, Ricardo, Sepulcros de la Casa Real de Castilla, Madrid, Instituto Jerónimo Zurita, CSIC, 1954.

Deswarte, Thomas, De la destruction à la restauration. L'idéologie du royaume d'Oviedo-León (VIIe-XIe siècles), Turnhout, Brepols, 2003.

Dierkens, Alain, Quelques réflexions sur la présentation des sarcophages dans les églises du Haut Moyen Âge, en Alduc-Le Gaousse, A. (ed.), Inhumations de prestige ou prestige de l'inhumation? Expressions du pouvoir dans l'audelà (IVe-XVe siècle), Caen, Publications du CRAHM, 2009, pp. 265-302.

Ellenius, Allan (ed.), Iconography, propaganda, and legitimation, Nueva York, Clarendon Press, 1998.

Español, Francesca, Els comtes d'Urgell i el seu Panteó dinàstic, en El comtat d'Urgell, Lleida, Universitat de Lleida - Institut d' Estudis Ilerdencs, 1995, pp. 149-183.

Español, Francesca, Els escenaris del rei. Art i monarquia a la Corona d'Aragó, Manresa, Angle, 2001.

Español, Francesca, El Gòtic català, Manresa, Angle, 2002.

Estepa, Carlos, El poder regio y los territorios, en La Época de la Monarquía Asturiana, Oviedo, Real Instituto de Estudios Asturianos, 2002, pp. 451-467.

Falque, Emma (ed.), Historia Compostelana, Madrid, Akal, 1994.

Falque, Emma, Lucas de Túy y Rodrigo Jiménez de Rada: el uso de las fuentes, "Cahiers de linguistique hispanique médiévale" 26 (2003), pp. 151-161.

Fernández Vallina, Emiliano, Sampiro y el llamado Silense, "Helmantica: Revista de filología clásica y hebrea" 29 (1978), pp. 51-60.

Flórez, Henrique, España Sagrada: tomo XXIII. Continuacion de las memorias de la santa iglesia de Tuy y coleccion de los chronicones pequeños publicados e ineditos de la historia de España, Madrid, Antonio Marin, 1767.

Gandavo, Henricus de, Opera Omnia, Quolibet IX, Lovaina, Leuven University Press, 1983.

Geary, Patrick J., La mémoire et l'oubli à la fin du premier millénaire, París, Aubier, 1996.

Giesy, Ralph E., Le roi ne meurt jamais: les obsèques royales dans la France de la Renaissance, París, Flammarion, 1987.

Gómez Rascón, Máximo, Sepulcro de Ordoño II, Madrid, Área de Comunicación e Imagen BBVA, Departamento de Actividades Culturales, 2005.

González, Julio, Regesta de Fernando II, Madrid, Instituto Jerónimo Zurita, CSIC, 1943.

González, Julio, Alfonso IX, Madrid, Instituto Jerónimo Zurita, CSIC, 1944.

Guiance, Ariel, Los discursos sobre la muerte en la Castilla medieval (siglos VII-XV), Valladolid, Junta de Castilla y León. Consejería de Educación y Cultura, 1998.

Gutiérrez Baños, Fernando, Las empresas artísticas de Sancho IV, Valladolid, Junta de Castilla y León. Consejería de Educación y Cultura, 1997.

Henry, Patrick, From Apostle to abbot: the legitimation of spiritual authority in the Early Church, "Studia Patristica" 17 (1982), pp. 491-505.

Henriet, Patrick (dir.), A la recherche de légitimités chrétiennes. Représentations de l'espace et du temps dans l'Espagne médiévale (IXe-XIIIe siècle), Lyon, ENS éd., 2003. (Annexes des Cahiers de linguistique et de civilisation hispaniques médiévales; 15).

Henriet, Patrick, Political struggle and the Legitimation of the Toletan Primacy: the Pars Lateranii Concilii, en Alfonso, I.; Kennedy, H.; Escalona, J. (eds.), 
Building legitimacy. Political discourses and forms of legitimation in Medieval Societies, Leiden - Boston, Brill, 2004, pp. 291-318.

Jerez Cabrero, Enrique, El Chronicon Mundi de Lucas de Tuy (ca. 1238): Técnicas compositivas y motivaciones ideológicas, Madrid, Universidad Autónoma de Madrid, 2006.

Jiménez de Rada, Rodrigo [Roderici Ximeni de Rada], Historia de Rebus Hispania sive Historia Gothica, Juan Fernández Valverde (ed.), Turnhout, Brepols, 1987.

Karge, Henrik, De la portada románica de la Transfiguración al Pórtico de la Gloria. Nuevas investigaciones sobre la fachada occidental de la catedral de Santiago de Compostela, "Boletín del Seminario de Arte y Arqueología" 75 (2009), pp. 17-30.

Karge, Henrik, De Santiago de Compostela a León: modelos de innovación en la arquitectura medieval española. Un intento historiográfico más allá de los conceptos de estilo, en Suárez Quevedo, D. (dir.), Cien años de investigación sobre arquitectura medieval española. Anales de Historia del Arte, Madrid, Publicaciones Universidad Complutense de Madrid, 2009, vol. extra 1, pp. 165-196.

Karge, Henrik, Die Kathedrale von Santiago de Compostela. Neue Forschungen zur Baugeschichte der romanischen Jakobuskirche, en Arbeiter, A.; Kothe, Ch.; Marten, B. (eds.), Hispaniens Norden im 11. Jahrhundert. Christliche Kunst im Umbruch / El Norte hispánico en el siglo XI. Un cambio radical en el arte cristiano, Petersberg, M. Imhof, 2009, pp. 183-199.

Karge, Henrik, Magdeburg, Santiago de Compostela, Toledo - Spolien und retrospektive Formmotive in der europäischen Architektur des Hochmittelalter, en Schattner, Th.G.; Valdéz Fernández, F. (eds.), Spolien im Umkreis der Macht / Spolia en el entorno del poder, Mainz am Rhein, P. von Zabern, 2009, pp. 229-246. (Iberia archaeologica; 12).

Kastner, Jörg, Historiae fundationum monasteriorum. Frühformen monastischer Institutionsgeschichtsschreibung im Mittelalter, Munich, Arbeo-Gesellschaft, 1974.

Kruger, Kristina, Fürstengrablegen in Nordspanien: die Panteones früh - und hochmittelalterlicher Kirchen, en Brongásser, B.; Karge, H.; Klein, B. (eds.), Grabkunst und Sepulkralkultur in Spanien und Portugal/Arte funerario y cultura sepulcral en España y Portugal, Frankfurt - Madrid, Vervuert - Iberoamericana, 2006, pp. 33-63.

Linehan, Peter, History and the Historians of Medieval Spain, Oxford, Clarendon Press, 1993.

Linehan, Peter, León, ciudad regia, y sus obispos en los siglos X-XIII, en El reino de León en la Alta Edad Media, vol. VI, León, Centro de Estudios e Investigación "San Isidoro" (CSIC-CECEL) - Caja España de Inversiones - Archivo Histórico Diocesano, 1994.

Linehan, Peter, Spain, 1157-1300: A Partible Inheritance, Malden - Oxford, Blackwell, 2008.

López Ferreiro, S., Historia de la Santa A. M. Iglesia de Santiago de Compostela, Santiago de Compostela, Impr. y enc. del Seminario Conciliar Central, 1898-1909.

Lucas Álvarez, Manuel, La documentación del Tumbo A de la Catedral de Santiago de Compostela, León, Centro de Estudios e Investigación "San Isidoro", 1997.

Marías, Fernando; Serra, Amadeo, La capilla Albornoz de la catedral de Toledo y los enterramientos monumentales de la España bajomedieval, en Guillaume, Jean, Demeures d'éternité: Eglises et chapelles funéraires aux XVe et XVIe siècles, París, Picard, 2005, pp. 33-48. 
Martin, Therese, Queen as King. Politics and Architectural Propaganda in Twelfth Century Spain, Leiden, Brill, 2006.

Martínez de Aguirre Aldaz, Javier, La primera escultura funeraria gótica en Sevilla: la Capilla Real y el sepulcro de Guzmán el Bueno (1248-1320), "Archivo Español de Arte" 270 (1995), pp. 111-129.

Martínez Tejera, Artemio M., El "Pórtico románico": origen y funcionalidad de un espacio arquitectónico intermedio de la edilicia medieval hispana (atrium/ porticus/vestibulum), en Huerta Huerta, P.L. (coord.), Espacios y estructuras singulares del edificio románico, Aguilar de Campoo, Fundación Santa María La Real - Centro Estudios del Románico, 2008, pp. 191-227.

Martínez Tejera, Artemio M., La arquitectura alto-medieval del reino astur y Alfonso II (791-842) ¿ Una edilicia neogoda? (en prensa).

Mattoso, Jose, A morte dos reis na Cronística Pré-Afonsina, "Estudos Medievais" 10 (1993), pp. 79-95.

Mattoso, Jose, O poder e a morte, "Anuario de Estudios Medievales" 25 (1995), pp. 395-427.

Menéndez Pidal, R. (ed.), Primera Crónica General de España, Madrid, Bailly-Baillière, 1906.

Menjot, Denis, Un chrétien qui meurt toujours: les funérailles Royales en Castille à la fin du Moyen Age, en Núñez, M.; Portela, E. (eds.), La idea y el sentimiento de la muerte en la historia y el arte de la Edad Media, Santiago de Compostela, Universidade de Santiago de Compostela, 1988, vol. I, pp. 127-138 [réed. en Denis Menjot, Dominar y controlar en Castilla en la Edad Media, Málaga, 2003, pp. 48-71].

Mitre, Emilio, La muerte del rey: la historiografía hispánica (1200-1348) y la muerte entre las élites, "En la España Medieval" 11 (1988), pp. 167-183.

Mitre, Emilio, La muerte primera y las otras muertes. Un discurso para las postrimerías en el Occidente Medieval, en Aurell, J.; Pavón, J. (eds.), Ante la muerte. Actitudes, espacios y formas en la España medieval, Pamplona, EUNSA Ediciones Universidad de Navarra, 2002, pp. 27-48.

Moralejo, Serafín, Esculturas compostelanas del último tercio del siglo XII, "Cuadernos de Estudios Gallegos" 28 (1973), pp. 294-310.

Moralejo, Serafín, La imagen arquitectónica de la Catedral de Santiago de Compostela, en Atti del Convengo Internazionale di Studi: Il Pellegrinaggio a Santiago di Compostella e la Letteratura Jacopea, Perugia, Università degli Studi di Perugia, 1983, pp. 37-61.

Moralejo, Serafín, Notas para una revisión de la obra de K. J. Conant, en Conant, Kenneth J., Arquitectura románica da Catedral de Santiago de Compostela, Santiago, Santiago, Colexio de Arquitectos de Galicia, 1983, pp. 221-236.

Moralejo, Serafín, El patronazgo artístico del arzobispo Gelmírez (1100-1140): su reflejo en la obra e imagen de Santiago, en Gai, L. (ed.), Atti del Convengo Internazionale di studi Pistoia e Il Cammino di Santiago. Una dimensiones europea nella Toscana medioevale, Nápoles, Edizione scientifiche italiane, 1984, pp. 245-272.

Moralejo, Serafín, La miniatura en los Tumbos A y B, en Díaz y Díaz, M.C. (ed.), Los tumbos de Compostela, Madrid, Banco Simeón - Edilán, 1985, pp. 45-62.

Moralejo, Serafín, ¿Raimundo de Borgoña $(\dagger 1107)$ o Fernando Alfonso $(\dagger 1214)$ ? Un episodio olvidado en la historia del Panteón Real compostelano, en Galicia en la Edad Media: actas del Coloquio de Santiago de Compostela, La Coruña, Pontevedra, Vigo, Betanzos, 13-17 Julio 1987, Madrid, Sociedad Española de Estudios Medievales, 1990, pp. 161-178. 
Moralejo, Serafín, La iconografía en el Reino de León (1157-1230), en Nuño González, J. (coord.), II Curso de Cultura Medieval. Alfonso VIII y su época, Madrid, Centro de Estudios del Románico, 1992, pp. 139-152.

Morales, Ambrosio de, Viaje a los Reinos de León, y Galicia, y Principado de Asturias (ed.facsímil): [según la edición de Enrique Flórez], Oviedo, Biblioteca Popular Asturiana, 1977.

Nicolai, Bernd; Rheidt, Klaus, Der westbau von Santiago de Compostela. Eine Kritische Revision, en Rückert, C.; Staebel, J. (eds.), Mittelalterliche Bauskulptur in Frankreich und Spanien, Frankfurt an Main - Madrid, Vervuert - Iberoamericana, 2010, pp. 341-352.

Nieto Soria, José Manuel, La Monarquía bajomedieval Castellana. ¿Una realeza Sagrada?, en Homenaje al profesor Juan Torres Fontes, Murcia, Universidad de Murcia, 1987, pp. 1225-1238.

Nieto Soria, José Manuel, Les clercs du roi et les origines de l'état moderne en Castille: propagande et legitimation (XIIIème-XVème siècles), "Journal of Medieval History" 18 (1992), pp. 297-318.

Nieto Soria, José Manuel, Propaganda and legitimation in Castile: religion and church, 1250-1500, en Ellenius, A. (ed.), Iconography, Propaganda, and Legitimation, Nueva York, Clarendon Press, 1998, pp. 105-119.

Nogales Rincón, David, La representación religiosa de la monarquía castellano-leonesa: la capilla real (1252-1504), Madrid, Universidad Complutense de Madrid, 2009. (Tesis doctoral).

Núñez, Manuel, Muerte coronada. El mito de los reyes en la Catedral compostelana, Santiago de Compostela, Universidade de Santiago de Compostela. Servicio de Publicacións e Intercambio Científico, 1999.

Otero Túñez, Ramón; Yzquierdo Perrín, Ramón, El coro del Maestro Mateo, La Coruña, Fundación Pedro Barrié de la Maza, 1990.

Pérez de Urbel, Justo, Sampiro, su crónica y la monarquía leonesa del siglo X, Madrid, CSIC, 1952.

Pérez de Urbel, Justo; González Ruiz-Zorrilla, A. (eds.), Historia Silense, Madrid, CSIC, 1959.

Pérez Monzón, Olga, Quando rey perdemos nunq[u]a bien nos fallamos... La muerte del rey en la Castilla del siglo XIII, "Archivo Español de Arte” 320 (2007), pp. 379-394.

Prada Marcos, María Encina; Vidal Encinas, Julio, La muerte de los reyes de León (siglos X-XI): aspectos históricos, arqueológicos y antropológicos desde el panteón de San Isidoro de León, en Quiroga, J.; Martínez Tejera A.M. (eds.), Morir en el Mediterráneo medieval, Oxford, John and Erica Hedges, 2009, pp. 239-320.

Prado Vilar, Francisco, Lacrimae rerum: San Isidoro de León y la memoria del padre, "Goya" 328 (2009), pp. 195-221.

Puente Mínguez, Juan A., El sepulcro del conde don Raimundo de Borgoña en la catedral de Santiago, en Barral, D.; López, J.M. (eds.), Estudios sobre Patrimonio Artístico. Homenaje del departamento de Historia del Arte y de la facultad de Geografía e Historia de la Universidad de Santiago de Compostela a la Prof. Dra. María del Socorro Ortega Romero, Santiago de Compostela, Xunta de Galicia, 2002, pp. 83-95.

Rico, Francisco, Alfonso el Sabio y la 'General Estoria', Tres lecciones, Barcelona, Ariel, 1984.

Ríos Saloma, Martín, La Reconquista: ¿una aspiración peninsular? Estudio comparativo entre dos tradiciones historiográficas, "Bulletin du CEM d'Auxerre" Hors série 2 (2008). http://cem.revues.org/document9702.html [consulta: 15/03/2012].

ANUARIO DE Estudios MEDIEVALES, 42/2, julio-diciembre 2012, pp. 535-565

ISSN 0066-5061, doi:10.3989/aem.2012.42.2.02 
Rodríguez Peña, M.A., El paradigma de los Reyes Sabios en el de De rebus Hispanae de Rodrigo Jiménez de Rada, en Sevilla, 1248. Congreso Internacional conmemorativa del 750 Aniversario de la Conquista de la Ciudad de Sevilla por Fernando III, Rey de Castilla y León, Madrid, Centro de Estudios Ramón Areces, 2000, pp. 757-765.

Rosell, Cayetano (ed.), Crónica de los reyes de Castilla desde don Alfonso el Sabio hasta los Católicos don Fernando y doña Isabel, Madrid, Atlas, 1953.

Rückert, Claudia; Staebel, Jochen, Der Pórtico de la Gloria, Meister Matheus und König Ferdinand, en Rückert, C.; Staebel, J. (eds.), Mittelalterliche Bauskulptur in Frankreich und Spanien, Frankfurt am Main - Madrid, Vervuert - Iberoamericana, 2010, pp. 353-366.

Rucquoi, Adeline, El rey sabio: cultura y poder en la monarquía medieval castellana, en Repoblación y reconquista. Actas del III curso de cultura medieval, Aguilar de Campoo, Centro de Estudios del Románico, 1991, pp. 77-87.

Rucquoi, Adeline, De los reyes que no son taumaturgos: los fundamentos de la realeza en España, "Temas Medievales" 5 (1995), pp. 163-186.

Ruiz Asencio, José Manuel, La inclusión del Chronicon de Sampiro en la Historia Silense, "Archivos Leoneses" 54 (1973), pp. 279-286.

Ruiz Asencio, José Manuel, Colección documental del archivo de la catedral de León (775-1230). IV (1032-1109), León, Centro de estudios e investigación San Isidoro - Caja de ahorros y monte de piedad - Archivo histórico diocesano, 1990.

Ruiz, Teófilo, Une royauté sans sacre: la monarchie castillane du bas moyen âge, "Annales ESC" 39 (1984), pp. 429-453.

Salazar y Acha, Jaime de, La casa del rey de Castilla y León en la Edad Media, Madrid, Centro de estudios políticos y constitucionales, 2000.

Sánchez Ameijeiras, Rocío, El 'cementerio real' de Alfonso VIII en Las Huelgas de Burgos, "Semata" 10 (1998), pp. 77-109.

Sánchez Ameijeiras, Rocío, The Eventful Life of the Royal Tombs of San Isidoro de León, en Martin, T.; Harris, J.A. (eds.), Church, State, Vellum, and Stone: Essays on Medieval Spain in Honor of John Williams, Leiden, Brill, 2005, pp. 479-520.

Sánchez Ameijeiras, Rocío, La memoria de un rey victorioso: los sepulcros de Alfonso VIII y la fiesta del triunfo de la Santa Cruz, en Brongásser, B.; Karge, H.; Klein, B. (eds.), Grabkunst und Sepulkralkultur in Spanien und Portugal/Arte funerario y cultura sepulcral en España y Portugal, Frankfurt am Main - Madrid, Vervuert - Iberoamericana, 2006, pp. 289-315.

Sánchez Ameijeiras, Rocío, El entorno imaginario del rey: cultura cortesana y/o cultura clerical en tiempos del Alfonso IX, en Alfonso IX e a súa época: pro utilitate regni mei, La Coruña - Madrid, Concello da Coruña - Ministerio de Cultura - Sociedad estatal de conmemoraciones culturales, 2008, pp. 307-326.

Sánchez Ameijeiras, Rocío, Dando forma al tiempo: estrategias visuales y cartularios ilustrados, "Studium Medievale" 2 (2009), pp. 61-84.

Sánchez Ameijeiras, Rocío, Sobre las modalidades y funciones de las imágenes en el Tumbo A, en Díaz y Díaz, Manuel; López Alsina, Fernando; Sánchez Ameijeiras, Rocío, Tumbo A, Índice de los Privilegios Reales que contiene este libro intitulado de la Letra A, Madrid, Testimonio Compañía Editorial, 2009.

Sauer, Christine, Fundatio und Memoria. Stifter und klostergründer im Bild 1100 bis 1350, Göttingen, Vandenhoeck \& Ruprecht, 1993.

Senra, José Luis, Ben per está aos reis d'amaren Santa Maria: la capilla de Nuestra Señora en el monasterio de San Salvador de Oña. Una iniciativa de Sancho IV el Bravo (1285) en el marco de un panteón funerario, en Dolores Barral, J.; López Vázquez, M. (eds.), Estudios sobre Patrimonio artístico. Home-

ANUARIO de Estudios Medievales, 42/2, julio-diciembre 2012, pp. 535-565

ISSN 0066-5061, doi:10.3989/aem.2012.42.2.02 
naje a la Prof. María del Socorro Ortega, Santiago de Compostela, Xunta de Galicia, 2002, pp. 141-163.

Serrano Coll, Marta, 'Semblança' de Martí l'Humà a través de la seva promoció artística, en Martí l'Humà, el darrer rei de la dinastia de Barcelona (13961410). L'interregne i el compromís de Casp, Barcelona, 2012, (en prensa).

Serrano, Luciano, El Obispado de Burgos y Castilla primitiva desde el siglo V al XIII, Madrid, Instituto Valencia de Don Juan, 1935-1936.

Shadis, Miriam, Piety, Poltics and Power: The Patronage of Leonor of England and Her Daughters Berenguela of León and Banche of Castile, en Hall, J. (ed.), The Cultural Patronage of Medieval Women, Athens, University of Georgia Press, 1996, pp. 202-227.

Smith, Damian J., James I and God: Legitimacy, protection and consolation in the 'Llibre dels Fets', "Imago temporis. Medium Aevum" 1 (2007), pp. 105-119.

Spiegel, Gabrielle M., The Past as Text. The Theory and Practice of Medieval Historiography, Baltimore - London, John Hopkins University, 1997.

Suárez González, Ana, ¿Del pergamino a la piedra? ¿De la piedra al pergamino?: entre diplomas, obituarios y epitafios medievales de San Isidoro de León, "Anuario de estudios medievales" 33/1 (2003), pp. 365-415.

Tellenbach, Gerd, Die historische Dimension der liturgischen commemoratio im Mittelalter, en Schmid, K.; Wollasch, J. (eds.), Memoria. Der geschichtliche Zeugniswert des liturgischen Gedenkens im Mittelalter, Munich, Wilhem Fink, 1984, pp. 200-214.

Tuy, Lucas de, Chronicon Mundi. Ab origine mundi usque ad eram MCCLXXIV; Crónica de España, J. Puyol (ed.), Madrid, [s.n.], 1926.

Tuy, Lucas de [Lucae Tudensis], Chronicon Mundi, Emma Falque (ed.), Turnhout, Brepols, 2003.

Vajay, Szabolcs de, From Alfonso VII to Alfonso X: the First Two Centuries of the Burgundian Dynasty in Castile and Leon. A Prosopographical Catalogue in Social Genealogy, 1100-1300, en Brook, L.L. (ed.), Studies in Genealogy and Family History in Tribute to Charles Evans on the Occasion of His Eightieth Birthday, Salt Lake City, Association for the Promotion of Scholarship in Genealogy, 1989, pp. 366-417.

Vones, Ludwig, Historiographie et politique: l'historiographie castillane aux abords $d u$ XIVe siècle, en Genet, J.-Ph. (ed.), L’historiographie médiévale en Europe, París, Editions du Centre national de la recherche scientifique, 1991, pp. 177-188.

Watson, Christabel, A Reassessment of the Western Parts of the Romanesque Cathedral of Santiago de Compostela, "Journal of the Society of Architectural Historians" 59/4 (2000), pp. 502-521.

Watson, Christabel, The Romanesque Cathedral of Santiago de Compostela: a reassessment, Oxford, Archaeopress, 2009.

Werner, Karl F., Les sources de la légitimité royale à l'avènement des Capétiens (XeXIe siècle), en Le sacre des rois. Actes du colloque international d'histoire sur les sacres et couronnements royaux (Reims, 1975), París, Belles Lettres, 1985, pp. 49-60.

Yzquierdo Perrín, Ramón, El Maestro Mateo y el Pórtico de la Gloria en la catedral de Santiago, León, Edilesa, 2010.

Fecha de recepción del artículo: diciembre 2010

Fecha de aceptación y versión final: mayo 2011 
